\title{
Economic Complexity and Environmental Performance: Evidence from a World Sample
}

\author{
Eirini Boleti ${ }^{1} \cdot$ Antonios Garas $^{2} \cdot$ Alexandra Kyriakou $^{3} \cdot$ Athanasios Lapatinas $^{4}$ (i)
}

Received: 15 February 2020 / Accepted: 19 January 2021 / Published online: 5 February 2021

(c) The Author(s) 2021

\begin{abstract}
In this paper, we analyze the relationship between economic complexity and environmental performance using annual data on 88 developed and developing countries for the period of 2002-2012. We use the Economic Complexity Index, which links a country's productive structure with the amount of knowledge and know-how embodied in the goods it produces, and the Environmental Performance Index as a measure of environmental performance. We show that moving to higher levels of economic complexity leads to better overall environmental performance, which means that sophistication of exported products does not induce environmental degradation. Nevertheless, we find that the effect of economic complexity on air quality is negative, i.e., exposure to $\mathrm{PM} 2.5, \mathrm{CO}_{2}$, methane and nitrous oxide emissions increases, and these findings are robust across alternative econometric specifications.
\end{abstract}

Keywords Economic complexity $\cdot$ Environmental performance $\cdot$ Pollution $\cdot \mathrm{CO}_{2}$ emissions

\section{Introduction}

Since the industrial revolution, new technologies have radically transformed sectors/industries, emphasizing the role of countries' economic structures on enhancing modernization of production. Structural transformationthe process by which economies diversify from agriculture to more sophisticated industries and services [23, 74, 80, 84,108 - directly affects the environment, by promoting for example the rapid growth of fossil fuel consumption and by producing significant levels of carbon dioxide $\left(\mathrm{CO}_{2}\right)$ emissions [86]. Although it is easy to highlight positive and negative impacts in particular sectors, it is much more difficult

$\mathrm{EB}, \mathrm{AG}, \mathrm{AK}$ and AL have contributed equally to the paper.

Athanasios Lapatinas

athanasios.lapatinas@ec.europa.eu

1 Department of Climate, Air and Sustainability, TNO, Princetonlaan 6, Utrecht 3584 CB, Netherlands

2 Chair of Systems Design, ETH Zurich, Weinbergstrasse 56/58, Zurich 8092, Switzerland

3 Department of Economics, University of Ioannina, P.O. Box 1186, Ioannina 45110, Greece

4 European Commission, Joint Research Centre (JRC), Via E. Fermi 2749, TP 361, Ispra (VA) I-21027, Italy to analyze and measure the overall environmental footprint of the reallocation of activities throughout the economy.

On the one hand, the transformation of the productive structure and the process of industrialization increase energy consumption and carbon emissions [88, 94, 143]. Some new production technologies developed in recent decades have had a far greater environmental impact than the ones they replaced. For example, in the agricultural sector, the traditional fertilizing system on farms, where animals provided the manure to fertilize the land, has been substituted by chemical fertilizers that have led to severe pollution problems (e.g., increase in nitrate and phosphate in drinking water and rivers, deterioration of soil fertility) because they contain heavy metals (e.g., cadmium and chromium) and high concentrations of radionuclides [21, 114].

On the other hand, the reallocation of factors of production from traditional to modern economic activities can also have positive effects by developing new means of reducing pollution and producing cleaner energy (e.g., solar panels, wind turbines, hydroelectricity, etc). Green technology and eco-innovation are decisively geared at lessening, if not reversing, the negative impacts of pollution by creating new products/services and business methods. These include among others, innovations in renewable energy, recycling, wastewater treatment, and 
eco-friendly food processing and packaging. The world market of environmental products and services is growing and policy makers are now paying more attention to the environmental goods and services (EGS) industry which is seen as a key ingredient of industrial competitiveness, trade advantage and social stability [40, 70, 79, 120].

In 2020, the EU is adopting an industrial strategy that will support the green transformation (the European Green Deal) by stimulating the development of new markets for climate-neutral and circular products and helping industries to modernize and exploit opportunities globally. The European Commission aims to present a 'sustainable products' policy which, among other priorities, will set minimum requirements to prevent environmentally harmful products from being placed on the EU market. ${ }^{1}$

From the above discussion, it becomes clear that structural changes of the economy can affect the environment in a number of ways. To disentangle the net effect of the process of structural transformation on environmental performance we employ the Economic Complexity Index (ECI), which quantifies the 'product space' of countries, i.e., the network representation of the products traded internationally.

The measure of economic complexity-which is explained in Appendix - quantifies a country's productive structure taking into account the sophistication of its exported goods relative to the sophistication of exported goods of the other countries and capturing differences in countries' industrial structures $[1,8,18,19,30,31,44,58$, $60,61,63,64,110,115,129]$.

In recent years, the ECI has received widespread attention throughout the scientific community, mainly because it is a robust predictor of economic growth [59, 63]. Furthermore, [58] have recently shown that countries exporting complex products tend to be more inclusive and have lower levels of income inequality than countries exporting simpler products. The authors attribute part of their finding to industrialization which played a major role in the rise of a new middle class by creating new jobs and training/education opportunities for workers.

Industrialization has also resulted in higher levels of pollution [11, 24, 102]. The relationship between industrialization and pollution has been investigated in numerous papers. Most of these use cross-country data and find a positive coefficient. A typical example is the work of York et al. [140], who show that in 146 countries, industrialization (measured as \% GDP from industry) monotonically increases energy use and $\mathrm{CO}_{2}$ emissions. Another example is Shafiei and Salim

\footnotetext{
1 'The European Green Deal', European Commission, Brussels, 11.12.2019 COM(2019) 640 final.
}

[116], who also find a positive relationship in 29 OECD countries for the period of 1980-2011. Asane-Otoo [13] shows that the industrialization process of middleincome African countries had a significant positive effect on their $\mathrm{CO}_{2}$ emissions. A positive and statistically significant relationship between industrialization and pollution is also found by Al-Mulali and Ozturk [6] in 14 Middle East and North African (MENA) countries for the period of 1996-2012. The positive relationship between the proportion of GDP from industry and air pollution is also verified by Martínez-Zarzoso et al. [96] for European Union member states during the period of 1975-1999. Extensive research also exists regarding the relationship between structural change and environmental degradation in China. Studies such as $[85,90,133,138$, 141] show that a country's structural transformation from agricultural to industrial production influences environmental quality in a negative way.

On the other hand, according to the 'three-sector analysis' [26, 46], as incomes rise and countries become more prosperous, the economy moves towards the tertiary sector (service-based) and the level of pollution decreases [34]. Then, demand for health, education, security and well-being increases, as well as the level of environmental awareness. The interest on the Environmental Kuznets Curve (EKC) has recently been revived [3, 5, 29, $33,35,50,83,97]$. Empirical studies on EKC have revisited the implications of structural transformations on the nexus between economic development and environmental performance [95].

Recent advancements in information and communication technologies (ICT) have raised concerns about 'technological pollution'. A priori, ICT seems to be harmful for the environment because its use implies higher energy consumption. Contrary to this perception, Romm [111] argues that ICT supports sustainable development as the growth of ICT is linked to reductions in energy intensity. According to Hilty et al. [65], ICT's impacts on environmental sustainability take the following three forms: primary effects, such as increasing electronic waste; secondary effects, such as improving the energy-efficiency of production; tertiary effects, such as inducing a productto-service shift in consumption and/or activating structural changes in economies' productive structures. Ollo-López and Aramendía-Muneta [104] show that the use of some ICT helps to reduce emissions, whereas others increase them. In general, there are no consistent results regarding the impact that ICT has on the environment, and the literature investigating this issue is scarce.

The above-mentioned studies show a clear relationship between structural transformations of the economy and the environment. In this work, we contribute to these two strands of literature by documenting a strong and robust 
relationship between the sophistication of a country's productive structure and its environmental performance. We find that higher levels of economic complexity are associated with better environmental performance, i.e., better health, higher life expectancy at birth and lower mortality rate under 5 , improved access to drinking water and sanitation, more terrestrial and marine protected areas, lower consumption of fossil fuels. On the other hand, higher complexity of exported products leads to lower air quality (i.e., higher exposure to PM2.5, higher $\mathrm{CO}_{2}$, methane and nitrous oxide emissions), higher energy use and lower renewable energy consumption. This result is consistent across various specifications in a global sample that includes 88 developed and developing countries over the period of 2002-2012.

The remainder of the paper is structured as follows. Section 2 provides a review of the relevant literature and discusses the connection between environmental performance and economic complexity. Section 3 describes the datasets used in the paper. Section 4 describes the econometric analysis for studying the effect of economic complexity on environmental outcomes and discusses the control and instrumental variables included in the econometric model. Section 5 presents the results and their robustness analysis. In Section 6, we draw our conclusions.

\section{Linking Economic Complexity and Environmental Performance}

According to Kaufmann et al. [78] the composition of the goods that a country produces is an important determinant of its environmental performance. High economic complexity implies a shift from a low-productivity agricultural economy to higher-productivity sectors and to the production of more sophisticated products. This shift requires increased consumption of energy resources, which in turn contributes to elevated $\mathrm{CO}_{2}$ emissions and environmental degradation. On the other hand, the ECI is related to structural transformations in the economy, and reflects the amount of knowledge and advanced capabilities embedded in the production process. Hence more complex countries offer better conditions for developing technological solutions that benefit the environment [99].

Green innovations stemming from more 'personbytes' in the economy, replace the old and environmentally harmful

\footnotetext{
${ }^{2}$ Hidalgo [62] argues that what Kuznets called 'measure of our ignorance' in his Nobel Prize acceptance speech is actually our individual mental capacity, our 'personbytes'.

${ }^{3}$ Mealy and Teytelboym [99] provide a review of the economic complexity applications to the green economy (subsection2.3).
}

technologies and the production process becomes cleaner and energy efficient. ${ }^{2}$ Gala et al. [48] suggest that economic complexity enhances the uptake of innovations while Gramkow and Anger-Kraavi [52] argue that the determinants of green innovations are similar to non-green innovations. Therefore, it is possible that economic complexity contributes to the absorption of green innovations, thus, improving the overall environmental performance.

Despite its potential importance, the relationship between economic complexity and the environment remains relatively unexplored. ${ }^{3}$ Only a few papers identify the ECI as a predictor of environmental outcomes, and most of them use carbon emissions to represent environmental quality.

Can and Gozgor [20] were the first to introduce ECI in a model that tests the EKC validity in the French economy for the period from 1964 to 2014. Their results illustrate that higher economic complexity suppresses the level of $\mathrm{CO}_{2}$ emissions in the long run. Neagu and Teodoru [101] examine the relationship between the ECI and environmental pollution within a panel of 25 European Union countries spanning the period from 1995 to 2016. Their findings show that economic complexity is positively associated with greenhouse gas emissions. Dogan et al. [36] use 55 countries over the period 1971 to 2014, which they divide into three different income groups. Their results indicate that the ECI affects $\mathrm{CO}_{2}$ emissions differently at the various stages of development and income, increasing the environmental degradation in lower and higher middle-income countries and abating $\mathrm{CO}_{2}$ emissions in high-income countries.

Instead of using pollutant emissions as dependent variable, Yilanci and Pata [139] adopt the ecological footprint (EF) to study the impact of ECI on the environment during the period 1965-2016, and show that China produces and exports environmentally unfriendly goods. Neagu [100] using a panel of 25 European Union countries from 1995 to 2017, suggests a nonlinear impact of economic complexity on the environment and describes this relationship as an inverted U-shaped curve, similar to the EKC for income. This result implies that a country's environment tends to degrade until a certain level of economic complexity is reached. Above this level of complexity, the quality of the environment begins to improve. In addition, Chu [25] confirms the EKC hypothesis for economic complexity using a wider dataset covering 118 countries for the period 2002 to 2014.

Finally, Swart and Brinkmann [126] focus on a single country, i.e. Brazil, to examine the relationship between the ECI and four environmental variables during the period 2002-2014. They show that forest fires increase linearly with ECI while waste generation decreases. However, they find no evidence of correlation between the ECI and deforestation or air pollution. 
Considering our discussion so far, it is clear that the ECI, as a major indicator of structural transformations and proxy for a country's innovative output [127], is an important determinant of environmental performance. Building upon this intuition we empirically test the hypothesis that two countries that differ in economic complexity- everything else being constant across countries-manifest differences in their environmental performance. That is, if a country moves to a higher level of economic complexity its environmental performance will be better. Furthermore, moving away from using carbon emissions to represent environmental pollution, to the best of our knowledge, this is the first work that uses a synthetic measure such as the Environmental Performance Index (EPI) to represent environmental quality.

In the following sections, we provide an analytical description of the used data, and we formally set the equation to be tested.

\section{Data}

Dataset 1: environmental performance We utilize the EPI which is a composite index of environmental quality developed by Yale University and Columbia University in collaboration with the World Economic Forum and the European Commission's Joint Research Centre. The EPI includes (i) emissions indicators for different pollutants, (ii) the effects of pollution on human health and environmental degradation, (iii) the existence and effectiveness of environmental policies. ${ }^{4}$

The EPI ranks how well countries perform on environmental policy outcomes (larger values mean better environmental performance) in two broad objectives including protection of human health from environmental degradation and maintaining ecosystem vitality. National performance on each objective is measured in nine policy categories including twenty proximity-to-target indicators using weights derived from principal component analysis and expert judgment (see Fig. 7 in EPI [39]).

Each of the two broad and inextricably linked objectives encompasses specific environmental policy issues. The environmental health objective includes health impacts (weight: $33 \%$ ), air quality (33\%) and water and sanitation $(33 \%)$. The ecosystem vitality objective includes water resources (25\%), agriculture (5\%), forests $(10 \%)$, fisheries $(10 \%)$, biodiversity and habitat $(25 \%)$, climate and energy (25\%). The nine policy categories are calculated as the weighted average of twenty underlying proximity-to-target indicators (i.e. they measure how

\footnotetext{
$\overline{{ }^{4} \text { For details }}$ on the database see http://sedac.ciesin.columbia.edu/ data/collection/epi. For the methodology, see $[39,69]$.
}

close countries are to meeting internationally established targets or how they perform with respect to the best performing countries).

We analyze the sensitivity of our baseline results using two alternative dependent variables: (a) $\mathrm{CO}_{2}$ emissions from fuel consumption obtained from the World Bank [15], and (b) average exposure to PM2.5, which is one of the EPI's components. Among the different pollutants, $\mathrm{CO}_{2}$ and PM2.5 are emitted from anthropogenic sources, are directly linked to economic activities and are considered to be two of the most serious hazards to human health at the global level [22, 37, 112]. As an alternative dependent variable, we have also used the World Bank's sum of energy consumption index. In this way, we additionally study the economic complexity and energy consumption nexus, as $\mathrm{CO}_{2}$ emissions are mostly generated by the use of fossil fuels. Table 1 summarizes the definitions of the variables, the sources, and presents some descriptive statistics.

Dataset 2: exports by product We use freely available international trade data from MIT's Observatory of Economic Complexity (http://atlas.media.mit.edu). We choose the SITC-4 rev.2 dataset, which provides the longest time series, combining information from a dataset compiled by Feenstra et al. [43] for the years 1962 to 2000 and the U.N. Comtrade dataset from 2001 to 2008 (https://comtrade.un.org), and which provides details about the products exported by each country.

Dataset 3: economic complexity The sophistication of a country's productive structure is measured by its economic complexity. We measure the economic complexity of countries using the Economic Complexity Index (ECI). The ECI quantifies the diversity and sophistication of a country's export structure, estimated from data connecting countries to the products they export, and is freely available from MIT's Observatory of Economic Complexity (http://atlas.media.mit.ed). The index is calculated by applying the methodology described in [60] on dataset 2 .

To check the robustness of our baseline results, we also use the improved Economic Complexity Index (ECI+). The ECI+ also measures the diversity and sophistication of a country's export structure, but is corrected for how difficult it is to export each product. The ECI+ is also freely available from MIT's Observatory of Economic Complexity. The index is calculated by applying the methodology described in [8] on dataset 2. Albeaik et al. [8] show that the ECI+ outperforms the original ECI in its ability to predict economic growth and in the consistency of its estimators across different econometric specifications. The ECI+ is calculated with simple linear algebra techniques that determine the knowledge intensity of economies endogenously (from the data) [8], recognizing that institutions, knowledge and technology are prerequisites for economic growth. In a very recent working paper, Albeaik et al. [7] show that the ECI+ is equivalent to the fitness complexity metric proposed by Tacchella et al. [128]. 
Table 1 Variable definitions, sources and summary statistics

\begin{tabular}{|c|c|c|c|c|}
\hline Variable & Definition & Source & Mean & Std. Dev. \\
\hline EPI & Environmental Performance Index & $\begin{array}{l}\text { Yale Center for Environmental Law and Policy } \\
\text { (YCELP) }\end{array}$ & 49.48 & 16.52 \\
\hline ECI & $\begin{array}{l}\text { Economic Complexity Index: measure of the } \\
\text { diversity and sophistication of a country's } \\
\text { export structure }\end{array}$ & MIT's Observatory of Economic Complexity & -0.004 & 0.999 \\
\hline ECI+ & $\begin{array}{l}\text { Improved measure of Economic Complexity } \\
\text { Index. See [8] }\end{array}$ & MIT's Observatory of Economic Complexity & -0.008 & 0.995 \\
\hline GDP per capita & $\begin{array}{l}\text { (log) GDP per capita, PPP (constant } 2011 \text { inter- } \\
\text { national \$) }\end{array}$ & World Development Indicators & 1.589 & 1.654 \\
\hline education & $\begin{array}{l}\text { Enrollment in secondary education, both sexes } \\
\text { (number) }\end{array}$ & World Development Indicators & $3.3 \mathrm{M}$ & $11.6 \mathrm{M}$ \\
\hline trade & Imports plus exports as \% of GDP & World Development Indicators & 89.93 & 48.25 \\
\hline agriculture & Agriculture, value added ( $\%$ of GDP) & World Development Indicators & 13.92 & 12.88 \\
\hline industry & Industry, value added (\% of GDP) & World Development Indicators & 29.52 & 12.57 \\
\hline population & $\begin{array}{l}\text { Population density (people per sq. km of land } \\
\text { area) }\end{array}$ & World Development Indicators & 159.73 & 528.97 \\
\hline corruption & $\begin{array}{l}\text { Re-scaled control of corruption index. Higher } \\
\text { scores correspond to better institutions. }\end{array}$ & Worldwide Governance Indicators & 2.41 & 1.007 \\
\hline urban & Urban population ( $\%$ of total) & World Development Indicators & 54.91 & 22.97 \\
\hline patents & $\begin{array}{l}\text { (log) Number of patents granted as distributed } \\
\text { by year of patent grant }\end{array}$ & U.S. Patent and Trademark Office & 3.37 & 2.85 \\
\hline articles & $\begin{array}{l}\text { (log) Number of scientific and technical journal } \\
\text { articles }\end{array}$ & $\begin{array}{l}\text { National Science Foundation, Science and Engi- } \\
\text { neering Indicators }\end{array}$ & 5.64 & 2.97 \\
\hline energy & (log) Energy use (kg of oil equivalent per capita) & World Development Indicators & 7.19 & 1.15 \\
\hline renew electricity & $\begin{array}{l}\text { (log) Renewable electricity output (\% of total } \\
\text { electricity output) }\end{array}$ & World Development Indicators & 2.744 & 1.322 \\
\hline renew energy & $\begin{array}{l}\text { (log) Renewable energy consumption (\% of total } \\
\text { final energy consumption) }\end{array}$ & World Development Indicators & 2.549 & 1.172 \\
\hline renew water & $\begin{array}{l}\text { (log) Renewable internal freshwater resources } \\
\text { per capita (cubic meters) }\end{array}$ & World Development Indicators & 8.313 & 1.635 \\
\hline fossil fuel cons & (log) Fossil fuel energy consumption (\% of total) & World Development Indicators & 4.274 & 0.335 \\
\hline health impacts & $\begin{array}{l}\text { EPI - Issue Category: Health Impacts (Weight- } \\
\text { ing 0.33) }\end{array}$ & $\begin{array}{l}\text { Yale Center for Environmental Law and Policy } \\
\text { (YCELP) }\end{array}$ & 81.68 & 18.60 \\
\hline mortality & $\begin{array}{l}\text { (log) Mortality rate, under-5 (per } 1000 \text { live } \\
\text { births) }\end{array}$ & World Development Indicators & 2.460 & 0.920 \\
\hline life expectancy & (log) Life expectancy at birth, total (years) & World Development Indicators & 4.305 & 0.091 \\
\hline water / sanitation & $\begin{array}{l}\text { EPI - Issue Category: Water and Sanitation } \\
\text { (Weighting 0.33) }\end{array}$ & $\begin{array}{l}\text { Yale Center for Environmental Law and Policy } \\
\text { (YCELP) }\end{array}$ & 66.70 & 28.47 \\
\hline biodiversity & $\begin{array}{l}\text { EPI - Issue Category: Biodiversity and Habitat } \\
\text { (Weighting 0.25) }\end{array}$ & $\begin{array}{l}\text { Yale Center for Environmental Law and Policy } \\
\text { (YCELP) }\end{array}$ & 62.45 & 25.10 \\
\hline air quality & $\begin{array}{l}\text { EPI - Issue Category: Air Quality (Weighting } \\
0.33 \text { ) }\end{array}$ & $\begin{array}{l}\text { Yale Center for Environmental Law and Policy } \\
\text { (YCELP) }\end{array}$ & 79.21 & 16.29 \\
\hline $\mathrm{CO}_{2}$ & $\begin{array}{l}\text { (log) } \mathrm{CO}_{2} \text { emissions (kg per } 2011 \text { PPP \$ of } \\
\text { GDP) }\end{array}$ & World Development Indicators & -1.53 & 0.69 \\
\hline methane & ( $\log )$ Methane emissions ( $\mathrm{kg}$ of $\mathrm{CO} 2$ equivalent) & World Development Indicators & 10.02 & 1.534 \\
\hline nitrous oxide & $\begin{array}{l}\text { (log) Nitrous oxide emissions (thousand metric } \\
\text { tons of } \mathrm{CO} 2 \text { equivalent) }\end{array}$ & World Development Indicators & 9.143 & 1.512 \\
\hline popgrow & Population growth (annual \%) & World Development Indicators & 1.55 & 1.65 \\
\hline popold & Population aged 65 and above ( $\%$ of total) & World Development Indicators & 7.39 & 5.13 \\
\hline political corruption & $\begin{array}{l}\text { Political corruption index. Higher values reflect } \\
\text { higher levels of corruption. }\end{array}$ & Varieties of Democracy Dataset version 6.2 & 0.524 & 0.279 \\
\hline rural & Rural population (\% of total population) & World Development Indicators & 44.74 & 23.01 \\
\hline tertiary education & Gross enrollment ratio, tertiary, both sexes (\%) & World Development Indicators & 35.31 & 26.67 \\
\hline
\end{tabular}


Table 1 (continued)

\begin{tabular}{|c|c|c|c|c|}
\hline Variable & Definition & Source & Mean & Std. Dev \\
\hline economic globalization & $\begin{array}{l}\text { Actual flows (trade, foreign direct investment, } \\
\text { stocks, portfolio investment, income payments } \\
\text { to foreign nationals), restrictions (hidden } \\
\text { import barriers, mean tariff rate, taxes on } \\
\text { international trade, capital account restric- } \\
\text { tions). Higher values reflect greater economic } \\
\text { globalization. }\end{array}$ & KOF Index of Globalization & 60.35 & 17.04 \\
\hline political globalization & $\begin{array}{l}\text { Embassies in country, membership in inter- } \\
\text { national organizations, participation in UN } \\
\text { security council missions, international } \\
\text { treaties. Higher values reflect greater political } \\
\text { globalization. }\end{array}$ & KOF Index of Globalization & 64.15 & 20.94 \\
\hline quality of government & $\begin{array}{l}\text { ICRG Indicator of Quality of Government. } \\
\text { Higher values indicate a higher quality of } \\
\text { government. }\end{array}$ & $\begin{array}{l}\text { International Country Risk Guide - The PRS } \\
\text { Group }\end{array}$ & 0.526 & 0.204 \\
\hline shadow & Level of the shadow economy & {$[38]$} & 32.39 & 12.68 \\
\hline executive constraints & Executive constraints (decision rules) & Polity IV Annual Time-Series, 1800-2015 & 5.04 & 2.02 \\
\hline
\end{tabular}

\section{Regression Analysis}

We study the effect of economic complexity on environmental performance using datasets 1 and 3 (see Section 3). Given the availability of controls, the sample covers 88 developed and developing countries over the period of 2002-2012. ${ }^{5}$

For the estimation, in order to control for potential endogeneity problems, we follow a fixed-effects two-stage least squares/instrumental variables (FE 2SLS/IV) strategy.

\subsection{Econometric Model}

We regress the baseline specification described by the following equation:

$$
\begin{aligned}
\mathrm{EPI}_{i, t} & =\alpha_{0}+\beta_{1} \mathrm{ECI}_{i, t}+\beta_{2} \log (G D P)_{i, t}+\beta_{3}\left[\log (G D P)_{i, t}\right]^{2} \\
& +\beta_{k} \text { controls }_{i, t}+\gamma_{i}+\delta_{t}+u_{i, t} .
\end{aligned}
$$

Here, the environmental performance of country $i$ in period $t\left(\mathrm{EPI}_{\mathrm{i}, \mathrm{t}}\right)$ depends on a country's economic complexity $\left(\mathrm{ECI}_{\mathrm{i}, \mathrm{t}}\right)$, which is the key regressor of our analysis, as well

\footnotetext{
5 OECD: Australia, Austria, Belgium, Canada, Chile, Czech Republic, Denmark, Estonia, Finland, France, Germany, Greece, Hungary, Ireland, Italy, Japan, Korea (Rep. of), Latvia, Mexico, Netherlands, New Zealand, Norway, Poland, Portugal, Slovak Republic, Slovenia, Spain, Sweden, Switzerland, Turkey, United Kingdom, United States; nonOECD: Algeria, Azerbaijan, Bangladesh, Belarus, Bolivia, Bosnia and Herzegovina, Brazil, Bulgaria, Cameroon, China, Colombia, Costa Rica, Croatia, Dominican Republic, Ecuador, Egypt, Arab Rep., El Salvador, Georgia, Ghana, Guatemala, Honduras, India, Indonesia, Iran, Jamaica, Jordan, Kazakhstan, Kenya, Kuwait, Lebanon, Lithuania, Macedonia FYR, Malaysia, Moldova, Morocco, Nigeria, Oman, Pakistan, Panama, Paraguay, Peru, Philippines, Qatar, Romania, Russian Federation, Saudi Arabia, Serbia, Singapore, South Africa, Sri Lanka, Thailand, Tunisia, Ukraine, Uruguay, Uzbekistan, Venezuela.
}

as the level of economic development in per capita terms, $\log (G D P)_{i, t}$ (taking also into account the Environmental Kuznets Curve empirical findings when considering the squared term of the $\log (G D P)_{i, t}$ per capita [27, 57, 92, $123,124,131])$, a set of control variables described in the next subsection, time $\delta_{t}$ and country $\gamma_{i}$ fixed effects, and a stochastic term $u_{i, t}$. To examine the robustness of our results and to generalize our findings, we also replicate our analysis for (a) energy consumption and renewable resources, (b) health impacts, water and sanitation, biodiversity and (c) air quality and emissions. In addition, we substitute the ECI with the ECI+, finding qualitatively similar results. In Section 5, we present and discuss our findings.

\subsection{Control Variables}

Based on previous literature, we include in the estimated equation a number of control variables that are likely related to environmental performance. First, in order to account for different stages of economic development, we use the logarithm of GDP per capita (PPP in constant 2011 international dollars) from the World Bank's World Development Indicators (WDI). According to the EKC hypothesis, there is an inverted U-shaped relationship between pollution indicators and economic development. To control for this, we add as an explanatory variable the quadratic specification of GDP per capita, GDP per capita ${ }^{2}$. Since the variable GDP per capita is highly correlated with its squared term, it has been demeaned to have a zero sample mean in order to reduce the collinearity problem (i.e., we center the linear term around its sample mean before taking the square) [4, 92, 109]. 
In addition, a nation's openness to international trade may have a significant impact on environmental quality. Studies on the relationship between trade and the environment give evidence of ambiguous effects [12, 28, $42,47,55,71,72,76]$. In order to investigate whether openness to trade influences environmental performance, we use the proportion of exports and imports in GDP, denoted as trade. Moreover, we control for the proportions of both agriculture and industry's value added in GDP to capture the composition of a country's output, denoted as agriculture and industry, respectively. We also include two demographic variables: population density (number of people per square kilometer of land area) and urban population (the proportion of urban population) to identify the consequences of demographic changes on the environment [66, 73, 87, 106, 119, 132]. Poor air and water quality, insufficient water availability, waste-disposal problems, and high energy consumption are exacerbated by the increasing population density and demands of urban areas. In many countries, most cities are growing at a faster rate than the national average, which puts pressure on urban resources and the environment. In developing countries, workers are migrating from rural to urban areas for better services and this could be considered an additional source of pollution [76]. On the other hand, urbanization may increase environmental awareness and lead to a more efficient exploitation of energy and natural resources. It is therefore possible for more densely populated areas to be less polluted $[68,118,130]$.

We also control for the level of human capital by employing the number of enrolled people in secondary education. This variable is expected to affect environmental sustainability because people with more education are more aware of and concerned about environmental hazards. They also tend to engage in actions that promote and support political decisions that protect the environment [16, 17, 107]. Finally, we include data on the control of corruption. The relevant literature distinguishes two partial effects that corruption may have on environmental pollution. On the one hand, corruption directly increases pollution by reducing the stringency of environmental regulations [32, 93] and/or the effectiveness with which they are enforced $[54,91] .^{6}$ On the other hand, corruption affects pollution indirectly by reducing output $[56,77,98]$, which in turn may lead to lower pollution at some income levels [53, 77, 117]. This implies that at the aggregate level, the size of the

\footnotetext{
${ }^{6}$ See also [82] who explore additional channels through which corruption may impact environmental quality in a theoretical model. See also the discussion in [92].
}

indirect effect could dominate the direct effect, leading to overall pollution going down $[27,51]$. In other words, the total effect of corruption on environmental quality cannot be determined a priori [136]. We adopt the measure of control of corruption provided by the World Bank's Worldwide Governance Indicators (WGI). The index has been re-scaled to range from 0 to 5.0, with higher scores corresponding to better institutions.

In Subsection 5.2, we verify the robustness of our results by adopting further control variables and/or using alternative measures for some of the above-mentioned controls.

\subsection{Instrumental Variables}

We estimate equation (1) using different econometric methods. First, we use pooled-OLS and then, fixedeffects-OLS. However, fixed effects estimators do not necessarily identify the effect of economic complexity on environmental performance. The estimation of the effect requires exogenous sources of variation. While we do not have an ideal source of exogenous variation recognized by previous studies, there are two promising potential instruments of ECI that we adopt in our fixedeffects 2SLS/IV analysis.

Firstly, we use the measure of the (log) number of journal articles published in scientific and technical journals in a given year. This index calculates the total number of papers in the fields of physics, biology, chemistry, mathematics, clinical medicine, biomedical research, engineering and technology, and earth and space sciences. Higher values are associated with a higher level of scientific effort and output, which is directly related to the intensity of process and product innovation in the economy i.e. to the sophistication of its productive structure.

The second instrument considered is the (log) number of patents granted per year from the US Patent and Trademark Office. There are works such as [135] showing that green patents significantly contribute to the environmental cleanup; however, our hypothesis here is that patents (and articles) impact environmental performance only indirectly, through the enhanced sophistication of products and means of production. In other words, both variables are expected to be correlated with economic complexity-we expect articles and patents to increase technological capabilities which, in turn, influence industrialization and products' sophistication (see [81])—without having a direct effect on environmental performance and this is validated by our estimations and the relevant statistical tests on the significance and relevance of the instruments (see the discussion in the next section). 
Table 2 The effect of economic complexity on environmental performance: pooled OLS

\begin{tabular}{|c|c|c|c|c|c|c|c|c|}
\hline & (1) & (2) & (3) & (4) & (5) & (6) & (7) & (8) \\
\hline$E C I$ & $\begin{array}{l}6.414 * * * \\
(0.331)\end{array}$ & $\begin{array}{l}4.869 * * * \\
(0.337)\end{array}$ & $\begin{array}{l}5.167 * * * \\
(0.343)\end{array}$ & $\begin{array}{l}3.904 * * * \\
(0.378)\end{array}$ & $\begin{array}{l}3.584 * * * \\
(0.408)\end{array}$ & $\begin{array}{l}3.459 * * * \\
(0.403)\end{array}$ & $\begin{array}{l}4.071 \text { *** } \\
(0.422)\end{array}$ & $\begin{array}{l}3.220 * * * \\
(0.39)\end{array}$ \\
\hline GDP per capita & $\begin{array}{l}7.805^{* * * *} \\
(0.321)\end{array}$ & $\begin{array}{l}7.770 * * * \\
(0.306)\end{array}$ & $\begin{array}{l}7.532 \text { *** } \\
(0.305)\end{array}$ & $\begin{array}{l}7.704 * * * \\
(0.437)\end{array}$ & $\begin{array}{l}6.891 * * * \\
(0.478)\end{array}$ & $\begin{array}{l}7.158 * * * \\
(0.476)\end{array}$ & $\begin{array}{l}6.541 * * * \\
(0.584)\end{array}$ & $\begin{array}{l}5.760 * * * \\
(0.576)\end{array}$ \\
\hline GDP per capita ${ }^{2}$ & $\begin{array}{l}0.443 * * * \\
(0.136)\end{array}$ & $\begin{array}{l}0.639 * * * \\
(0.149)\end{array}$ & $\begin{array}{l}0.658 * * * \\
(0.149)\end{array}$ & $\begin{array}{l}0.883 * * * \\
(0.157)\end{array}$ & $\begin{array}{l}0.651 * * * \\
(0.169)\end{array}$ & $\begin{array}{l}0.591 * * * \\
(0.165)\end{array}$ & $\begin{array}{c}0.14 \\
(0.182)\end{array}$ & $\begin{array}{l}-0.262 \\
(0.179)\end{array}$ \\
\hline Population & & & $\begin{array}{l}-0.006 * * * \\
(0.001)\end{array}$ & $\begin{array}{l}-0.006 * * * \\
(0.001)\end{array}$ & $\begin{array}{l}-0.006^{* * *} \\
(0.001)\end{array}$ & $\begin{array}{l}-0.006^{* * *} \\
(0.001)\end{array}$ & $\begin{array}{l}-0.005^{* * *} \\
(0.001)\end{array}$ & $\begin{array}{l}-0.006^{* * *} \\
(0.001)\end{array}$ \\
\hline Agriculture & & & & $\begin{array}{l}-0.115^{* * *} \\
(0.038)\end{array}$ & $\begin{array}{l}-0.106 * * * \\
(0.038)\end{array}$ & $\begin{array}{l}-0.140 * * * \\
(0.039)\end{array}$ & $\begin{array}{l}-0.129 * * * \\
(0.046)\end{array}$ & $\begin{array}{l}-0.157 * * * \\
(0.044)\end{array}$ \\
\hline Industry & & & & $\begin{array}{l}-0.057 * * * \\
(0.022)\end{array}$ & $\begin{array}{l}-0.028 \\
(0.022)\end{array}$ & $\begin{array}{l}-0.049 * * \\
(0.023)\end{array}$ & $\begin{array}{c}0.005 \\
(0.027)\end{array}$ & $\begin{array}{c}0.012 \\
(0.026)\end{array}$ \\
\hline Corruption & & & & & $\begin{array}{l}1.248 * * * \\
(0.377)\end{array}$ & $\begin{array}{l}1.036 \text { *** } \\
(0.371)\end{array}$ & $\begin{array}{l}2.144 * * * \\
(0.383)\end{array}$ & $\begin{array}{l}1.186 \text { *** } \\
(0.354)\end{array}$ \\
\hline Trade & & & & & & $\begin{array}{l}0.023 * * * \\
(0.005)\end{array}$ & $\begin{array}{c}0.006 \\
(0.005)\end{array}$ & $\begin{array}{l}0.015 * * * \\
(0.005)\end{array}$ \\
\hline Urban & & & & & & & $\begin{array}{c}0.028 \\
(0.02)\end{array}$ & $\begin{array}{c}0.026 \\
(0.02)\end{array}$ \\
\hline Education & & & & & & & $\begin{array}{l}-0.000 * * * \\
(0.000)\end{array}$ & $\begin{array}{l}-0.000 * * * \\
(0.000)\end{array}$ \\
\hline$O E C D$ & & & & & & & & $\begin{array}{l}6.523 * * * \\
(0.774)\end{array}$ \\
\hline Observations & 1283 & 1210 & 1210 & 1160 & 1160 & 1149 & 940 & 940 \\
\hline R-squared & 0.814 & 0.855 & 0.857 & 0.865 & 0.866 & 0.87 & 0.89 & 0.9 \\
\hline F-statistic & 555.8 & 525.3 & 521.8 & 479 & 466.7 & 460.2 & 483.9 & 526.2 \\
\hline
\end{tabular}

Dependent variable: Environmental Performance Index (EPI). Main independent variable: Economic Complexity Index (ECI). Time fixed effects are included in all regressions. Regional dummies are also included: europe, asia, oceania, north america, south america. Robust standard errors in parentheses

$* p<0.10$;** $p<0.05 ; * * * p<0.01$

\section{Empirical Results}

\subsection{The Effect of Economic Complexity on Environmental Performance}

In this section, we discuss our baseline findings, i.e., the results when estimating equation (1) with different econometric techniques. Table 2 reports the results of pooled-OLS, adding additional variables from the set of controls in each step (column). In all specifications, we consider time fixed effects. In all columns except (1), we adopt a set of regional dummies for geographical heterogeneity, which is related to latitude, climatic conditions, and ecological awareness. Namely, we use the following dummies: Europe, Asia, Oceania, North America, South America. In column (8), we also adopt the dummy variable $O E C D$ to isolate the effect of high levels of economic development on environmental quality [49, 89, 92]. As expected, the sign of the estimated coefficient is positive because of the higher environmental awareness in developed countries. In all specifications, economic complexity has a positive relationship with environmental performance and the control variables enter with the expected sign. The education coefficient is negative, though its magnitude is negligible.

In columns (1)-(5) of Table 3, we estimate equation (1) with fixed-effects OLS panel regressions. We use time dummies and robust standard errors (in parentheses). In all cases, the ECI is a positive and statistically significant predictor of environmental performance. The statistically significant and positive squared term of the (log) GDP per capita predicts that environmental quality improves at higher incomes, which is in accordance with the EKC hypothesis that the relationship between pollution and economic development follows an inverse U-shaped form [53, 67, 117]. Notably, when we control for economic complexity, the declining part of the EKC is even more pronounced than when we do not (column 
Table 3 The effect of economic complexity on environmental performance: baseline results

\begin{tabular}{|c|c|c|c|c|c|c|}
\hline & $\begin{array}{l}\text { (1) } \\
\text { FE OLS }\end{array}$ & $\begin{array}{l}\text { (2) } \\
\text { FE OLS }\end{array}$ & $\begin{array}{l}\text { (3) } \\
\text { FE OLS }\end{array}$ & $\begin{array}{l}\text { (4) } \\
\text { FE OLS }\end{array}$ & $\begin{array}{l}\text { (5) } \\
\text { FE OLS }\end{array}$ & $\begin{array}{l}\text { (6) } \\
\text { FE 2SLS/IV }\end{array}$ \\
\hline$E C I$ & $\begin{array}{l}0.650 * * * \\
(0.233)\end{array}$ & $\begin{array}{l}0.765 * * * \\
(0.257)\end{array}$ & $\begin{array}{l}0.778 * * * \\
(0.256)\end{array}$ & $\begin{array}{l}1.042 * * * \\
(0.317)\end{array}$ & & $\begin{array}{l}5.519 * * * \\
(1.46)\end{array}$ \\
\hline GDP per capita & $\begin{array}{l}0.177 \\
(0.772)\end{array}$ & $\begin{array}{l}0.32 \\
(0.572)\end{array}$ & $\begin{array}{l}0.326 \\
(0.595)\end{array}$ & $\begin{array}{l}0.121 \\
(0.762)\end{array}$ & $\begin{array}{l}0.752 \\
(0.713)\end{array}$ & $\begin{array}{l}-3.069^{* * *} \\
(1.023)\end{array}$ \\
\hline GDP per capita ${ }^{2}$ & $\begin{array}{l}0.498 * \\
(0.297)\end{array}$ & $\begin{array}{l}0.674 * * * \\
(0.239)\end{array}$ & $\begin{array}{l}0.782 * * * \\
(0.267)\end{array}$ & $\begin{array}{l}0.563 * \\
(0.311)\end{array}$ & $\begin{array}{l}0.081 \\
(0.38)\end{array}$ & $\begin{array}{l}0.770 * * \\
(0.382)\end{array}$ \\
\hline Population & $\begin{array}{l}-0.002^{* * *} \\
(0.001)\end{array}$ & $\begin{array}{l}-0.002 * * * \\
(0.001)\end{array}$ & $\begin{array}{l}-0.002 * * * \\
(0.001)\end{array}$ & $\begin{array}{l}-0.008 \\
(0.006)\end{array}$ & $\begin{array}{l}-0.007 \\
(0.005)\end{array}$ & $\begin{array}{l}-0.006 * * \\
(0.003)\end{array}$ \\
\hline Agriculture & & $\begin{array}{l}0.016 \\
(0.021)\end{array}$ & $\begin{array}{l}0.007 \\
(0.023)\end{array}$ & $\begin{array}{l}0.016 \\
(0.033)\end{array}$ & $\begin{array}{l}0.016 \\
(0.023)\end{array}$ & $\begin{array}{l}-0.116^{* * *} \\
(0.053)\end{array}$ \\
\hline Industry & & $\begin{array}{l}0.013 \\
(0.015)\end{array}$ & $\begin{array}{l}0.011 \\
(0.015)\end{array}$ & $\begin{array}{l}0.030 * \\
(0.018)\end{array}$ & $\begin{array}{l}0.043 * * \\
(0.02)\end{array}$ & $\begin{array}{l}0.023 \\
(0.025)\end{array}$ \\
\hline Corruption & & & $\begin{array}{l}-0.14 \\
(0.33)\end{array}$ & $\begin{array}{l}-0.025 \\
(0.347)\end{array}$ & $\begin{array}{l}-0.387 \\
(0.414)\end{array}$ & $\begin{array}{l}0.359 \\
(0.352)\end{array}$ \\
\hline Trade & & & $\begin{array}{l}0.005 \\
(0.005)\end{array}$ & $\begin{array}{l}0.002 \\
(0.005)\end{array}$ & $\begin{array}{l}0 \\
(0.003)\end{array}$ & $\begin{array}{l}-0.009 \\
(0.007)\end{array}$ \\
\hline Urban & & & & $\begin{array}{l}-0.088 \\
(0.061)\end{array}$ & $\begin{array}{l}-0.037 \\
(0.056)\end{array}$ & $\begin{array}{l}-0.223 * * * \\
(0.055)\end{array}$ \\
\hline Education & & & & $\begin{array}{l}-0.000 \\
(0.000)\end{array}$ & $\begin{array}{l}-0.000 \\
(0.000)\end{array}$ & $\begin{array}{l}-0.000 \\
(0.000)\end{array}$ \\
\hline \multicolumn{7}{|l|}{ Fist-stage results } \\
\hline Patents & & & & & & $\begin{array}{l}0.050 * * * \\
(0.013)\end{array}$ \\
\hline Articles & & & & & & $\begin{array}{l}0.128 * * * \\
(0.036)\end{array}$ \\
\hline Observations & 1283 & 1227 & 1216 & 985 & 1394 & 736 \\
\hline Countries & 117 & 114 & 114 & 110 & 160 & 88 \\
\hline R-squared & 0.495 & 0.552 & 0.557 & 0.576 & 0.494 & 0.417 \\
\hline F-test & & & & & & 13.09 \\
\hline DWH-test & & & & & & 13.94 \\
\hline Weak-id & & & & & & 20.88 \\
\hline LM-weakid & & & & & & 25.08 \\
\hline Hansen ( $\mathrm{p}$ value) & & & & & & 0.8 \\
\hline
\end{tabular}

Dependent variable: Environmental Performance Index (EPI). Main independent variable: Economic Complexity Index (ECI). All regressions include time dummies. Robust standard errors in parentheses. F-test gives the F-statistic for the joint significance of the instruments in the first stage. DWH-test is the DurbinWu-Hausman test of endogeneity of the regressors. LM-weakid gives the Kleibergen-Paap Wald test of weak identification. Weak-id gives the Cragg-Donald F-statistic for weak identification. Hansen (p value) gives the $p$ value of the Hansen test of overidentification

$* p<0.10$; ** $p<0.05 ; * * * p<0.01$
5). In addition, the role of industry in terms of value added as \% of GDP seems to be statistically important for environmental quality. Together, all variables explain $57.6 \%$ of the variance in environmental performance among countries and across time (column 4), but ECI is the most significant variable in the regression analysis, and it is also the variable that explains the largest percentage of the variance in environmental performance after the effects of all other variables have been taken into account. The semi-partial correlation of ECI (the difference in R-squared between the full model and one in which only ECI was removed) is $8.2 \%$, meaning that $8.2 \%$ of the variance in environmental performancewhich is not accounted for by the other macroeconomic variables-is explained by ECI. This in turn implies that ECI contains information about environmental performance that cannot be explained by these other variables. 


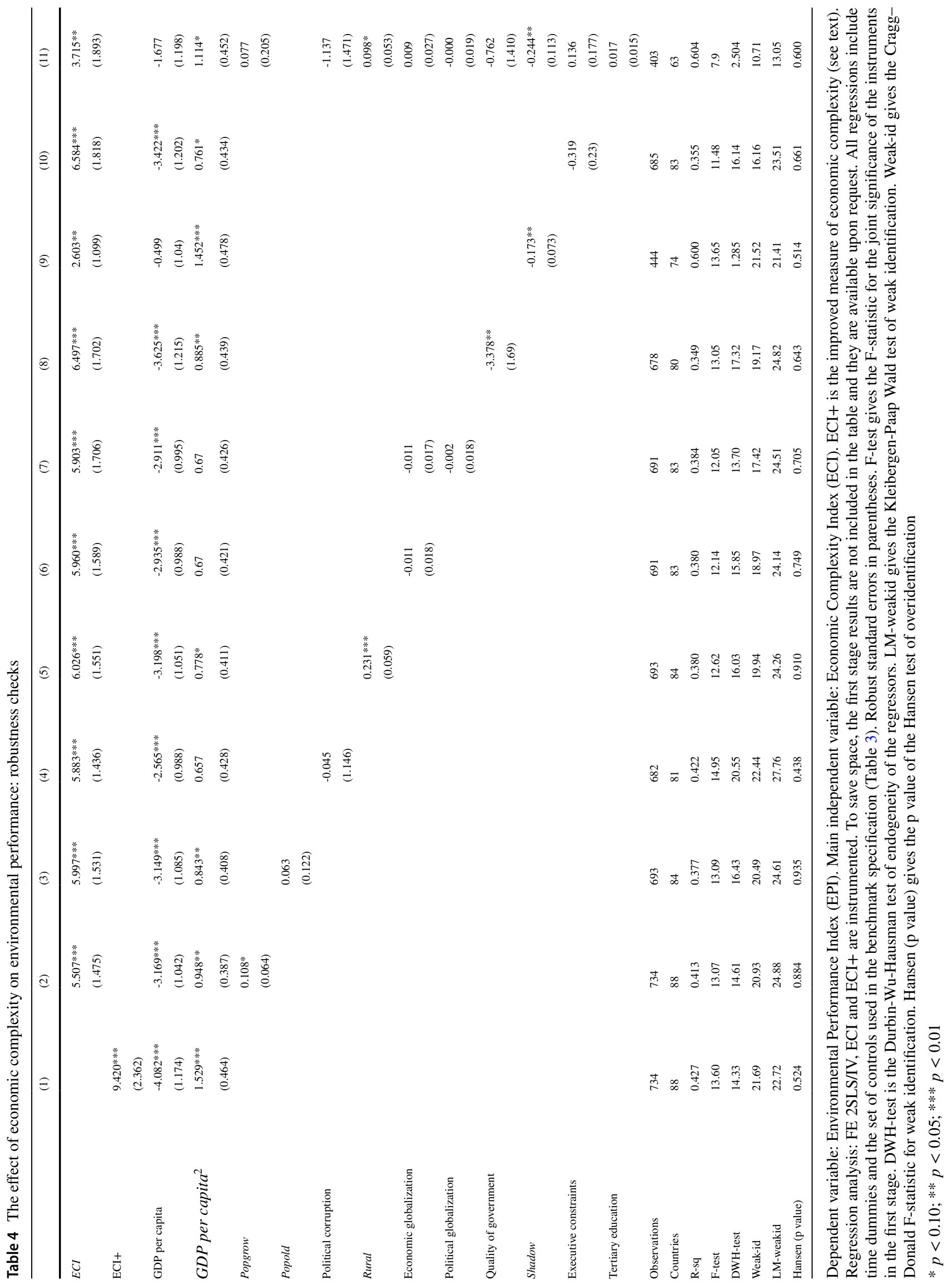


The fixed-effects 2 SLS/IV results in column (6) verify that the effect of a country's economic complexity on its environmental performance is positive. In fact, we find that an increase in economic complexity of one standard deviation is associated with an improvement of 5.5 in the EPI (standard deviation: 16.5). This positive effect of economic complexity on environmental performance is robust to the inclusion of measures of GDP per capita, population density (people per square kilometer of land area), agriculture value added (\% of GDP), industry value added (\% of GDP), control of corruption, trade (\% of GDP), urban population (\% of total), and enrollment in secondary education. In the fixed-effects 2SLS/IV estimation we report (a) the $F$-test for the joint significance of the instruments in the first stage: the rule of thumb is to exceed 10 [125]; (b) the Durbin-Wu-Hausman $(D W H)$ test of endogeneity of regressors: the null hypothesis that the IV regression is not required is rejected; (c) the Cragg-Donald F-statistic (Weak-id) that tests the relevance of the instruments in the first-stage regression: no evidence of instruments having a low correlation with the endogenous regressor after controlling for the exogenous regressors; (d) the Kleibergen-Paap Wald test (LM-weakid) of weak identification: the null hypothesis that the model is weakly identified is rejected; (e) the p value of Hansen's test of overidentification: the acceptance of the null indicates that the overidentifying restrictions cannot be rejected.

Concluding this section, the above analysis suggests that countries with more sophisticated productive structures, tend to have significantly higher environmental performance than countries exporting simple products. Furthermore, exploiting the temporal variation in the data, the fixed-effects panel regression and the fixedeffects 2SLS/IV analysis reveal a positive, statistically significant and robust effect of economic complexity on environmental performance. This suggests that the ECI must be taken into consideration by the policy makers when designing environmental policies as complex products can incorporate green industrial technologies. Producing and exporting complex goods that are associated with better environmental performance must be a priority when economic policies are shaped and national energy and environmental targets are set out by the countries. Our results imply that one mechanism by which a country can improve its environmental quality is to change its economic structure towards the production of goods that have, on average, a higher level of sophistication. Using fiscal and financial incentives, policy makers can promote investments in innovative/sophisticated activities which in turn develop the countries' ability to upgrade the quality of their environment.

\subsection{The Effect of Economic Complexity on Environmental Performance: Sensitivity Analysis}

In this subsection, we investigate the robustness of our baseline findings. First, we use an alternative measure of economic complexity, namely the improved Economic Complexity Index (ECI+) developed by MIT's Observatory of Economic Complexity. The ECI+ outperforms the original ECI in its ability to capture the difficulty of exporting each product. Second, we investigate whether the effect of economic complexity on environmental performance survives under additional and/or alternative control measures. Third, we consider the effect of economic complexity on energy consumption and renewable resources. This is by itself a substantially interesting issue, and as discussed in Section 1, an increasing number of empirical studies investigate the relationship between industrialization and energy use, typically finding a positive effect. Fourth, we check the robustness of our results with the EPIsubcategories related to health impacts (considering also measures for mortality and life expectancy), access to water/ sanitation and biodiversity. Fifth, considering the EPI's component of air quality as the dependent variable, which accounts equally for household air quality, average exposure to PM2.5 and PM2.5 exceedance, we replicate our baseline analysis studying the effect of economic complexity on this measure of air pollution. However, since $\mathrm{CO}_{2}$ emissions is the most widely used measure of pollutant emissions in the literature, we also estimate the main specification using this measure as the dependent variable, backing up our previous results. Additionally, we test the sensitivity of our model considering emissions such as methane and nitrous oxide.

\subsubsection{Improved Measure of Economic Complexity $(\mathrm{ECl}+)$}

Column (1) in Table 4 reports the estimates using the baseline fixed-effects 2SLS/IV specification and ECI+ as an alternative measure of economic complexity (the regression includes the set of controls used in the benchmark specification and time dummies). The baseline results remain qualitatively intact. Particularly, the coefficient of ECI+ is positive and statistically significant in the instrumented regression. On average, keeping all other variables constant at their mean values, an increase of 1 point in the ECI+ increases the EPI by 9.4 points. The level of development, measured by $(\log ) G D P$ per capita, again shows a non-linear impact on environmental performance. The EKC hypothesis also appears to be affirmed with the ECI+ as explanatory variable. The negative coefficient of the GDP per capita variable combined with the positive sign of its squared term confirms the inverse U-shaped relationship between pollution and economic development. 
Table 5 The effect of economic complexity on environmental performance: energy consumption and renewable resources

\begin{tabular}{|c|c|c|c|c|c|}
\hline & $\begin{array}{l}\text { (1) } \\
\text { Energy }\end{array}$ & $\begin{array}{l}(2) \\
\text { Renew electricity }\end{array}$ & $\begin{array}{l}\text { (3) } \\
\text { Renew energy }\end{array}$ & $\begin{array}{l}(4) \\
\text { Renew water }\end{array}$ & $\begin{array}{l}(5) \\
\text { Fossil fuel } \\
\text { cons }\end{array}$ \\
\hline$E C I$ & $\begin{array}{l}0.147 * \\
(0.085)\end{array}$ & $\begin{array}{l}-0.090 \\
(0.419)\end{array}$ & $\begin{array}{l}-0.681 * * * \\
(0.262)\end{array}$ & $\begin{array}{l}-0.027 \\
(0.077)\end{array}$ & $\begin{array}{l}-0.143 * \\
(0.079)\end{array}$ \\
\hline GDP per capita & $\begin{array}{l}0.644 * * * \\
(0.072)\end{array}$ & $\begin{array}{l}-0.695 * * \\
(0.285)\end{array}$ & $\begin{array}{l}-0.875 * * * \\
(0.212)\end{array}$ & $\begin{array}{l}0.060 \\
(0.071)\end{array}$ & $\begin{array}{l}0.320 * * * \\
(0.052)\end{array}$ \\
\hline GDP per capita ${ }^{2}$ & $\begin{array}{l}-0.084 * * * \\
(0.024)\end{array}$ & $\begin{array}{l}0.375 * * * \\
(0.114)\end{array}$ & $\begin{array}{l}0.248 * * * \\
(0.077)\end{array}$ & $\begin{array}{l}0.007 \\
(0.028)\end{array}$ & $\begin{array}{l}-0.060 * * * \\
(0.018)\end{array}$ \\
\hline Population & $\begin{array}{l}0.000 \\
(0.000)\end{array}$ & $\begin{array}{l}-0.001 \\
(0.001)\end{array}$ & $\begin{array}{l}-0.000 \\
(0.000)\end{array}$ & $\begin{array}{l}-0.003 * * * \\
(0.000)\end{array}$ & $\begin{array}{l}0.000^{*} \\
(0.000)\end{array}$ \\
\hline Agriculture & $\begin{array}{l}0.012 * * * \\
(0.003)\end{array}$ & $\begin{array}{l}0.004 \\
(0.012)\end{array}$ & $\begin{array}{l}-0.023^{* * *} \\
(0.009)\end{array}$ & $\begin{array}{l}-0.002 \\
(0.004)\end{array}$ & $\begin{array}{l}0.003 \\
(0.003)\end{array}$ \\
\hline Industry & $\begin{array}{l}0.008 * * * \\
(0.002)\end{array}$ & $\begin{array}{l}-0.023 * * * \\
(0.007)\end{array}$ & $\begin{array}{l}-0.009 * \\
(0.005)\end{array}$ & $\begin{array}{l}-0.005^{* *} \\
(0.002)\end{array}$ & $\begin{array}{l}0.002 \\
(0.001)\end{array}$ \\
\hline Corruption & $\begin{array}{l}0.022 \\
(0.02)\end{array}$ & $\begin{array}{l}0.222 * * \\
(0.107)\end{array}$ & $\begin{array}{l}-0.131 * * \\
(0.061)\end{array}$ & $\begin{array}{l}0.009 \\
(0.022)\end{array}$ & $\begin{array}{l}0.007 \\
(0.017)\end{array}$ \\
\hline Trade & $\begin{array}{l}0.000 \\
(0.000)\end{array}$ & $\begin{array}{l}0.009 * * * \\
(0.002)\end{array}$ & $\begin{array}{l}0.006 * * * \\
(0.001)\end{array}$ & $\begin{array}{l}0.002 * * * \\
(0.000)\end{array}$ & $\begin{array}{l}0.001 * \\
(0.000)\end{array}$ \\
\hline Urban & $\begin{array}{l}0.008 * * \\
(0.003)\end{array}$ & $\begin{array}{l}-0.017 \\
(0.017)\end{array}$ & $\begin{array}{l}0.009 \\
(0.008)\end{array}$ & $\begin{array}{l}0.000 \\
(0.003)\end{array}$ & $\begin{array}{l}0.006^{*} \\
(0.003)\end{array}$ \\
\hline Education & $\begin{array}{l}0.000 \\
(0.000)\end{array}$ & $\begin{array}{l}0.000 * * \\
(0.000)\end{array}$ & $\begin{array}{l}-0.000 \\
(0.000)\end{array}$ & $\begin{array}{l}0.000 \\
(0.000)\end{array}$ & $\begin{array}{l}-0.000 \\
(0.000)\end{array}$ \\
\hline Observations & 736 & 719 & 722 & 189 & 729 \\
\hline Countries & 88 & 84 & 85 & 70 & 87 \\
\hline R-squared & 0.465 & 0.289 & 0.255 & 0.736 & 0.151 \\
\hline F-test & 13.09 & 14.17 & 13.96 & 3.412 & 14.11 \\
\hline DWH-test & 4.697 & 2.858 & 7.375 & 0.187 & 1.192 \\
\hline Weak-id & 20.88 & 22.87 & 22.46 & 4.434 & 22.37 \\
\hline LM-weakid & 25.08 & 26.29 & 25.93 & 5.867 & 26.49 \\
\hline Hansen ( $p$ value) & 0.332 & 0.013 & 0.010 & 0.974 & 0.349 \\
\hline
\end{tabular}

Dependent variable: as noted in columns. Main independent variable: Economic Complexity Index (ECI). Regression analysis: FE 2SLS/IV. To save space, the first stage results are not included in the table. These are available upon request. All regressions include time dummies. Robust standard errors in parentheses. F-test gives the F-statistic for the joint significance of the instruments in the first stage. DWH-test is the Durbin-Wu-Hausman test of endogeneity of the regressors. LM-weakid gives the Kleibergen-Paap Wald test of weak identification. Weak-id gives the Cragg-Donald F-statistic for weak identification. Hansen ( $p$ value) gives the $\mathrm{p}$ value of the Hansen test of overidentification

$* p<0.10 ; * * p<0.05 ; * * * p<0.01$

\subsubsection{Alternative/Additional Controls}

Columns (2)-(10) in Table 4 start from the benchmark specification with the full set of controls (column (6) of Table 3) and introduce additional variables or alternative measures for some of the previous controls. Specifically, in column (2) we substitute the population density variable with population growth (\%), popgrow. Another alternative measure of population density that also captures differences in countries' demographic characteristics is employed in column (3), namely the proportion of the total population aged 65 and above, popold. In column (4) the corruption variable was substituted by the political corruption index found in the 'Varieties of Democracy Dataset', version 6.2. In column (5), we use rural population (\% of total) instead of urban population, finding the opposite sign (a positive effect), as expected. Columns (6) and (7) employ two measures of globalization, namely economic globalization and political globalization (from the KOF index of globalization) to control for countries' openness instead of trade. Column (8) introduces the International Country Risk Guide (ICRG) index of quality of government, establishing the robustness of our findings to the use of institutional quality measures. The coefficient has a negative 
sign, but when the control variables are considered all together (column (11)), it has no statistical significance. In column (9), we adopt a measure of the level of shadow economy, which seems to have a negative relationship with environmental performance. In column (10), the executive constraints variable, from the Polity IV Project, is an alternative measure of institutional quality. Finally, in column (11) we estimate the baseline model (a) considering all of the control variables together and (b) substituting the number of people enrolled in secondary education with the gross enrollment ratio (\%) in tertiary education. Adding these controls in our estimations leaves the findings qualitatively and quantitatively intact.

\subsubsection{Energy Consumption and Renewable Resources}

The relationship between economic growth, environmental pollution and energy consumption has been studied thoroughly in recent decades, using data from different countries and regions. Most studies are for single countries $[9,10,55,121,122,134,142]$ and only a few papers have used multi-country data to investigate this relationship, producing ambiguous results $[2,42,76,105$, 113].

Table 5 reports the estimation results of the benchmark specification but using (log) energy consumption ( $\mathrm{kg}$ of oil equivalent per capita) as the dependent variable in column (1); $(\log )$ renewable electricity output (\% of total electricity output), renew electricity, in column (2); (log) renewable energy consumption (\% of total final energy consumption), renewenergy, in column (3); (log) renewable internal freshwater resources per capita (cubic meters), renew water, in column (4); (log) fossil fuel energy consumption (\% of total), fossil fuel cons, in column (5). Economic complexity has a positive effect on energy use and the same effect stands for the level of income. However, for higher stages of economic development, it seems that energy consumption is less intensive (the squared term of GDP per capita has a negative coefficient). Both agriculture and industry sectors seem to be energy demanding, and as expected, a higher proportion of urban population is associated with higher energy consumption.

For the variables linked to renewable resources only the coefficient of renew energy is statistically significant, while the negative sign implies a negative effect of economic complexity on renewable energy consumption. Income has the same effect but for higher income levels the consumption of renewable energy increases. In addition, agriculture, industry and corruption have a negative effect on renew energy but trade increases the consumption of renewable energy. However, the negative sign of the fossil fuel cons coefficient in column (5) (statistically significant at the $10 \%$ level) provides evidence that complex economies tend to rely less on fossil fuels.
Nevertheless, environmental performance is not only influenced by production practices, but, by the consumption of goods as well. For instance, food and energy consumption account for a large part of the environmental impact. This leads to complex interactions between consumption patterns, production activities and environmental impacts [45]. Therefore, the signs and significance of ECI can vary with the dependent variable, not always in what would be the expected direction. For example, in the specifications (columns) 2-4 of Table 5, higher economic complexity is expected to have a positive effect in promoting renewable resources e.g. through the development of innovative renewable-based infrastructures. However, this effect is counterbalanced by the cost of renewable technologies, which is still high compared to traditional energy sources, and for many developing countries this high cost is a substantial obstacle in expanding their production and use of renewable energy.

\subsubsection{Health Impacts, Water and Sanitation, Biodiversity}

As discussed in Section 3, the EPI is a composite index that ranks countries' performance in the following two broad policy areas: (a) protection of human health from environmental harm and (b) vitality of ecosystems. The first component accounts for $40 \%$ of the EPI's total score and includes health impacts (33\%), air quality (33\%) and water and sanitation (33\%).

In Table 6, we check the robustness of our results by re-running the benchmark fixed-effects 2SLS/IV regression with the following EPI issue categories: health impacts (column 1), access to water/sanitation (column 4) and biodiversity (column 5). Furthermore, in columns 2 and 3 we test our model using the $(\log )$ mortality rate under 5 per 1000 live births and $(\log )$ total life expectancy at birth (years) respectively.

Our results show that economic complexity has an improving effect on all the above measures: higher economic complexity leads to (a) better health, higher life expectancy at birth and lower mortality rate under 5; (b) improved access to water and sanitation; (c) higher biodiversity and habitat (more protected terrestrial biome areas, marine protected areas, critical habitat protection).

\subsubsection{Air Quality and Emissions ( $\mathrm{CO}_{2}$, Methane and Nitrous Oxide)}

In this subsection, we check the sensitivity of our model by adopting the air quality component of the EPI and various measures of emissions as dependent variables. In this way, we focus on the effect of economic sophistication on air quality, leaving out of the equation the human well-being factors and the other "non-emission" variables. Column (1) 
Table 6 The effect of economic complexity on environmental performance: health impacts, water and sanitation, biodiversity

\begin{tabular}{|c|c|c|c|c|c|}
\hline & $\begin{array}{l}(1) \\
\text { Health impacts }\end{array}$ & $\begin{array}{l}(2) \\
\text { Mortality }\end{array}$ & $\begin{array}{l}\text { (3) } \\
\text { Life expectancy }\end{array}$ & $\begin{array}{l}\text { (4) } \\
\text { Water/Sanitation }\end{array}$ & $\begin{array}{l}(5) \\
\text { Biodiver- } \\
\text { sity }\end{array}$ \\
\hline$E C I$ & $\begin{array}{l}14.345^{* * *} \\
(3.012)\end{array}$ & $\begin{array}{l}-0.413^{* * *} \\
(0.107)\end{array}$ & $\begin{array}{l}0.021^{*} \\
(0.012)\end{array}$ & $\begin{array}{l}18.392 * * * \\
(5.287)\end{array}$ & $\begin{array}{l}18.834 * * * \\
(7.214)\end{array}$ \\
\hline GDP per capita & $\begin{array}{l}-3.171 \\
(2.660)\end{array}$ & $\begin{array}{l}-0.175^{* *} \\
(0.081)\end{array}$ & $\begin{array}{l}-0.015 * \\
(0.008)\end{array}$ & $\begin{array}{l}-2.868 \\
(3.716)\end{array}$ & $\begin{array}{l}-9.409 * * \\
(4.629)\end{array}$ \\
\hline GDP per capita ${ }^{2}$ & $\begin{array}{l}-0.132 \\
(0.905)\end{array}$ & $\begin{array}{l}0.032 \\
(0.029)\end{array}$ & $\begin{array}{l}-0.005 \\
(0.003)\end{array}$ & $\begin{array}{l}-1.081 \\
(1.224)\end{array}$ & $\begin{array}{l}2.329 \\
(1.865)\end{array}$ \\
\hline Population & $\begin{array}{l}0.002 \\
(0.005)\end{array}$ & $\begin{array}{l}0.000^{* *} \\
(0.000)\end{array}$ & $\begin{array}{l}0.000 \\
(0.000)\end{array}$ & $\begin{array}{l}-0.011 * \\
(0.006)\end{array}$ & $\begin{array}{l}-0.014 * \\
(0.008)\end{array}$ \\
\hline Agriculture & $\begin{array}{l}-0.073 \\
(0.136)\end{array}$ & $\begin{array}{l}0.011 * * * \\
(0.003)\end{array}$ & $\begin{array}{l}-0.001 * * * \\
(0.000)\end{array}$ & $\begin{array}{l}-0.117 \\
(0.180)\end{array}$ & $\begin{array}{l}0.070 \\
(0.234)\end{array}$ \\
\hline Industry & $\begin{array}{l}-0.045 \\
(0.046)\end{array}$ & $\begin{array}{l}0.005 * * * \\
(0.002)\end{array}$ & $\begin{array}{l}0.000 \\
(0.000)\end{array}$ & $\begin{array}{l}0.104 \\
(0.077)\end{array}$ & $\begin{array}{l}0.055 \\
(0.120)\end{array}$ \\
\hline Corruption & $\begin{array}{l}0.656 \\
(0.695)\end{array}$ & $\begin{array}{l}-0.031 \\
(0.026)\end{array}$ & $\begin{array}{l}-0.002 \\
(0.003)\end{array}$ & $\begin{array}{l}1.528 \\
(1.061)\end{array}$ & $\begin{array}{l}3.331 * \\
(1.739)\end{array}$ \\
\hline Trade & $\begin{array}{l}-0.039 * * * \\
(0.012)\end{array}$ & $\begin{array}{l}-0.001 \\
(0.000)\end{array}$ & $\begin{array}{l}0.000 \\
(0.000)\end{array}$ & $\begin{array}{l}-0.077 * * * \\
(0.023)\end{array}$ & $\begin{array}{l}-0.055^{* * *} \\
(0.027)\end{array}$ \\
\hline Urban & $\begin{array}{l}-0.196^{*} \\
(0.107)\end{array}$ & $\begin{array}{l}0.012 * * * \\
(0.004)\end{array}$ & $\begin{array}{l}-0.001 \\
(0.000)\end{array}$ & $\begin{array}{l}-0.058 \\
(0.160)\end{array}$ & $\begin{array}{l}-0.955^{* * * *} \\
(0.269)\end{array}$ \\
\hline Education & $\begin{array}{l}0.000 * * * \\
(0.000)\end{array}$ & $\begin{array}{l}0.000 \\
(0.000)\end{array}$ & $\begin{array}{l}0.000 \\
(0.000)\end{array}$ & $\begin{array}{l}0.000 * \\
(0.000)\end{array}$ & $\begin{array}{l}0.000 \\
(0.000)\end{array}$ \\
\hline Observations & 736 & 736 & 693 & 736 & 736 \\
\hline Countries & 88 & 88 & 84 & 88 & 88 \\
\hline R-squared & 0.270 & 0.782 & 0.730 & -0.132 & 0.035 \\
\hline F-test & 13.09 & 13.09 & 12.62 & 13.09 & 13.09 \\
\hline DWH-test & 27.96 & 16.08 & 6.042 & 16.93 & 8.379 \\
\hline Weak-id & 20.88 & 20.88 & 19.94 & 20.88 & 20.88 \\
\hline LM-weakid & 25.08 & 25.08 & 24.26 & 25.08 & 25.08 \\
\hline Hansen ( $p$ value) & 0.001 & 0.240 & 0.146 & 0.523 & 0.916 \\
\hline
\end{tabular}

Dependent variable: as noted in columns. Main independent variable: Economic Complexity Index (ECI). Regression analysis: FE 2SLS/IV. To save space, the first stage results are not included in the table. These are available upon request. All regressions include time dummies. Robust standard errors in parentheses. F-test gives the F-statistic for the joint significance of the instruments in the first stage. DWH-test is the Durbin-Wu-Hausman test of endogeneity of the regressors. LM-weakid gives the Kleibergen-Paap Wald test of weak identification. Weak-id gives the Cragg-Donald F-statistic for weak identification. Hansen $(p$ value) gives the $\mathrm{p}$ value of the Hansen test of overidentification

$* p<0.10$;** $p<0.05$; *** $p<0.01$ of Table 7 shows that the effect of economic complexity on air quality is negative (at the $10 \%$ level of statistical significance). The EKC hypothesis is verified again by the statistically significant positive coefficient of the squared GDP per capita. Regarding the rest of the control variables, population, agriculture and corruption enter the equation with a negative sign, while trade seems to have a positive effect.

Columns (2), (3) and (4) compare the finding above with the results when the $(\log ) \mathrm{CO}_{2}$ (the most commonly used indicator of air pollution in the literature), (log) methane and $(\log )$ nitrous oxide emissions are used. The effect of economic complexity on these emissions is positive and statistically significant. The squared term of GDP per capita is negative and population, agriculture, industry and corruption all have a statistically significant positive sign for the case of $\mathrm{CO}_{2}$ emissions. Our results also show that trade and urban population have a negative effect on methane and nitrous oxide emissions.

The above results verify that although economic complexity has a positive effect on the composite and comprehensive measure of a country's environmental performance, this is not the case for air quality. Explicitly, it seems that when an economy accelerates from an agricultural productive structure 
Table 7 The effect of economic complexity on environmental performance: air quality and emissions

\begin{tabular}{|c|c|c|c|c|}
\hline & $\begin{array}{l}\text { (1) } \\
\text { Air- } \\
\text { quality }\end{array}$ & $\begin{array}{l}(2) \\
\mathrm{CO} 2\end{array}$ & $\begin{array}{l}(3) \\
\text { Methane }\end{array}$ & $\begin{array}{l}(4) \\
\text { Nitrous } \\
\text { oxide }\end{array}$ \\
\hline$E C I$ & $\begin{array}{l}-6.209 * \\
(3.531)\end{array}$ & $\begin{array}{l}0.311 * * \\
(0.133)\end{array}$ & $\begin{array}{l}0.503 * * * \\
(0.133)\end{array}$ & $\begin{array}{l}0.561 * * * \\
(0.167)\end{array}$ \\
\hline GDP per capita & $\begin{array}{l}-3.122 \\
(2.672)\end{array}$ & $\begin{array}{l}-0.139 \\
(0.109)\end{array}$ & $\begin{array}{l}0.116 \\
(0.117)\end{array}$ & $\begin{array}{l}0.248 * \\
(0.138)\end{array}$ \\
\hline GDP per capita ${ }^{2}$ & $\begin{array}{l}3.344 * * * \\
(1.18)\end{array}$ & $\begin{array}{l}-0.161 * * * \\
(0.04)\end{array}$ & $\begin{array}{l}-0.070 \\
(0.053)\end{array}$ & $\begin{array}{l}-0.116^{* *} \\
(0.046)\end{array}$ \\
\hline Population & $\begin{array}{l}-0.028^{*} \\
(0.015)\end{array}$ & $\begin{array}{l}0.001 * \\
(0.000)\end{array}$ & $\begin{array}{l}0.000 \\
(0.000)\end{array}$ & $\begin{array}{l}0.000 \\
(0.000)\end{array}$ \\
\hline Agriculture & $\begin{array}{l}-0.336^{* * *} \\
(0.125)\end{array}$ & $\begin{array}{l}0.016 * * * \\
(0.006)\end{array}$ & $\begin{array}{l}-0.001 \\
(0.006)\end{array}$ & $\begin{array}{l}0.003 \\
(0.009)\end{array}$ \\
\hline Industry & $\begin{array}{l}-0.014 \\
(0.065)\end{array}$ & $\begin{array}{l}0.008 * * * \\
(0.002)\end{array}$ & $\begin{array}{l}0.002 \\
(0.002)\end{array}$ & $\begin{array}{l}0.004 \\
(0.003)\end{array}$ \\
\hline Corruption & $\begin{array}{l}-3.622 * * * \\
(0.863)\end{array}$ & $\begin{array}{l}0.068 * * \\
(0.035)\end{array}$ & $\begin{array}{l}0.015 \\
(0.036)\end{array}$ & $\begin{array}{l}0.073 * \\
(0.040)\end{array}$ \\
\hline Trade & $\begin{array}{l}0.037 * * \\
(0.016)\end{array}$ & $\begin{array}{l}-0.001 \\
(0.001)\end{array}$ & $\begin{array}{l}-0.002 * * * \\
(0.001)\end{array}$ & $\begin{array}{l}-0.001 * * \\
(0.001)\end{array}$ \\
\hline Urban & $\begin{array}{l}-0.166 \\
(0.104)\end{array}$ & $\begin{array}{l}0.006 \\
(0.004)\end{array}$ & $\begin{array}{l}-0.010 * * \\
(0.004)\end{array}$ & $\begin{array}{l}-0.010^{*} \\
(0.005)\end{array}$ \\
\hline Education & $\begin{array}{l}-0.000^{* * *} \\
(0.000)\end{array}$ & $\begin{array}{l}0.000 \\
(0.000)\end{array}$ & $\begin{array}{l}-0.000 \\
(0.000)\end{array}$ & $\begin{array}{l}0.000 \\
(0.000)\end{array}$ \\
\hline Observations & 736 & 736 & 732 & 732 \\
\hline Countries & 88 & 88 & 88 & 88 \\
\hline R-squared & 0.366 & 0.364 & -0.512 & -0.143 \\
\hline F-test & 13.09 & 13.09 & 13.26 & 13.26 \\
\hline DWH-test & 4.745 & 7.94 & 21.01 & 12.81 \\
\hline Weak-id & 20.88 & 20.88 & 21.23 & 21.23 \\
\hline LM-weakid & 25.08 & 25.08 & 25.36 & 25.36 \\
\hline Hansen (p value) & 0.135 & 0.143 & 0.039 & 0.032 \\
\hline
\end{tabular}

Dependent variable: as noted in columns. Main independent variable: Economic Complexity Index (ECI). Regression analysis: FE 2SLS/ IV. To save space, the first stage results are not included in the table. These are available upon request. All regressions include time dummies. Robust standard errors in parentheses. F-test gives the F-statistic for the joint significance of the instruments in the first stage. DWH-test is the Durbin-Wu-Hausman test of endogeneity of the regressors. LM-weakid gives the Kleibergen-Paap Wald test of weak identification. Weak-id gives the Cragg-Donald F-statistic for weak identification. Hansen ( $p$ value) gives the $p$ value of the Hansen test of overidentification

$* p<0.10 ; * * p<0.05 ; * * * p<0.01$

to a more sophisticated one with industrial and technological sectors, the effect on overall environmental performance is positive but the particular effect on air quality is negative.

The result that economic complexity decreases air quality is consistent with the findings of Dogan et al. [36] for $\mathrm{CO}_{2}$ emissions in lower- and higher-middle-income countries and [101] for greenhouse gas emissions in EU.
Furthermore, this result combined with our finding of a negative effect of economic complexity on renewable energy consumption suggests the following policy implication to suppress the level of emissions: Policymakers should focus on promoting investments in eco-friendly renewable energy such as solar, wind, hydro, tidal, geothermal and biomass sectors. For the EU, the 'sustainable products' policy of the European Commission's Green Deal strategy must provide incentives for developing renewable energy technologies and sophisticated green inputs, processes and products. And of course, speeding-up the transition from coal to renewable resources is important for the EU's commitment to reach carbon neutrality by 2050 and for the global effort to implement the Paris Agreement.

\section{Conclusions}

Our analysis illustrates that the environmental performance of a country is highly correlated with the mix of products that it exports. In a panel data setting, we have verified that there is a robust positive (resp. negative) relationship between environmental performance (resp. air quality) and product sophistication. Moreover, the effect of economic complexity on environmental performance has been verified with fixed-effects instrumental variables estimation techniques. Thus, the evidence presented in the paper suggests that the countries that produce sophisticated products are associated with improved environmental performance but also with inferior air quality (higher exposure to $\mathrm{PM} 2.5$, higher $\mathrm{CO}_{2}$, methane and nitrous oxide emissions). Explicitly, it seems that when an economy accelerates from an agricultural productive structure to a more sophisticated one which includes industrial and technological sectors, the effect on overall environmental performance is positive but the particular effect on air quality is negative.

Hence, the ECI could be a valuable tool for monitoring and assessing policies promoting and ensuring more sustainable and more environmentally-respectful production cycles, such as the European Green Deal, and/or evaluating smart specialization strategies and sectoral reallocation policies towards economic activities that are associated with better environmental performance and lower air pollution. Furthermore, according to WHO [137], exposure to air pollution has been found to have both direct and indirect detrimental effects on human health. The direct effects include respiratory irritation, chronic respiratory symptoms, heart diseases, lung cancer, premature mortality and reduced life expectancy $[41,75,103]$. The indirect mechanisms relate to pulmonary oxidative stress and inflammatory responses. Hence, our results about the effect of economic sophistication on air quality should also be considered valuable to policy makers. 
In sum, this study identifies economic complexity as an explanatory variable of the observed differences in environmental footprints across countries. However, we do not attempt to address the questions of why some countries have a higher level of economic complexity than others and what are the particular economic capabilities that are linked to greener production. Nevertheles, even though addressing these questions is beyond the scope of this paper, we do believe that they pose an interesting way forward.

\section{Appendix}

\section{Economic Complexity Indices: Methods}

\section{Economic Complexity Index (ECl) and Product Complexity Index (PCl)}

To calculate the measures of economic complexity used in this work, we rely on the methodology described in [60]. In short, let us assume that we have trade information for $l$ number of countries and $k$ products. With this information, we can fill an $(l \times k)$ exports matrix $\mathbf{E}$, so that matrix element $E_{i j}$ is equal to the monetary value country $i$ gains by exporting product $j$. Of course, if country $i$ does not export product $j$, then $E_{i j}=0$. From this matrix, it is easy to calculate the ratio between the share of a given product in a country's exports and the share of this product in the total global exports. This ratio is called Revealed Comparative Advantage (RCA) [14], and is given by

$\mathrm{RCA}_{c p}=\frac{X_{c p} / \sum_{p^{\prime}} X_{c p^{\prime}}}{\sum_{c^{\prime}} X_{c^{\prime} p} / \sum_{c^{\prime} p^{\prime}} X_{c^{\prime} p^{\prime}}}$,

where $X_{c p}$ is the total value of product $p$ exports by country $c$. As discussed previously in $[19,58,63]$, a country has a comparative advantage in a product (in other words, is a competitive exporter of a product) when $\mathrm{RCA}_{\mathrm{cp}} \geq 1$.

Using this threshold value, we obtain the $(l \times k)$ matrix M, with matrix elements $M_{c p}=1$ if country $c$ has an RCA for product $p$, and zero otherwise.

This matrix can be viewed as the incidence matrix of a bipartite network linking countries to products.

From this matrix, [63] introduced the ECI as a measure of the production characteristics of different countries. To obtain the ECI, we calculate the $(l \times l)$ square matrix $\tilde{\mathbf{M}}$. In short, matrix $\tilde{\mathbf{M}}$ provides information about links connecting two countries $c$ and $c^{\prime}$, based on the number of products they both export. The matrix elements $\tilde{M}_{c c^{\prime}}$ are computed as

$\tilde{M}_{c c^{\prime}}=\frac{1}{k_{c, 0}} \sum_{p} \frac{M_{c p} M_{c^{\prime} p}}{k_{p, 0}}$, where $k_{c, 0}=\sum_{p} M_{c p}$ measures the diversification of country $c$ in terms of the number of different products it exports, and $k_{p, 0}=\sum_{c} M_{c p}$ measures the number of countries that export a certain product $p$. If $\mathbf{K}$ is the eigenvector of $\tilde{\mathbf{M}}$ associated with the second largest eigenvalue, then according to Hausmann et al. [60], the ECI is calculated as

$\mathrm{ECI}=\frac{\mathrm{K}-\langle\mathbf{K}\rangle}{\operatorname{std}(\mathbf{K})}$.

In a similar manner, if instead of countries we place the spotlight on individual products, we can calculate the Product Complexity Index (PCI). In this case, the $(k \times k)$ matrix $\tilde{\mathbf{M}}$ will provide information about links connecting two products $p$ and $p^{\prime}$, based on the number of countries that export them both. Therefore, the matrix elements $\tilde{M}_{p p^{\prime}}$ are computed as

$\tilde{M}_{p p^{\prime}}=\frac{1}{k_{p, 0}} \sum_{c} \frac{M_{c p} M_{c p^{\prime}}}{k_{c, 0}}$,

and if $\mathbf{Q}$ is the eigenvector of $\tilde{\mathbf{M}}$ associated with the second largest eigenvalue,

$\mathrm{PCI}=\frac{\mathrm{Q}-\langle\mathbf{Q}\rangle}{\operatorname{std}(\mathbf{Q})}$.

\section{Improved Measure of Economic Complexity $(\mathrm{ECl}+)$}

To calculate the improved measure of economic complexity (ECI+) used in this work, we rely on the methodology described in Albeaik et al. [8].

In short, let us assume that we have trade information for $l$ number of countries and $k$ products.

We can calculate the total exports of a country corrected by how difficult it is to export each product using

$\mathrm{X}_{c}^{1}=\sum_{p} \frac{X_{c p}}{\sum_{c} \frac{X_{c p}}{X_{c}^{0}}}$

where $X_{c}^{0}=\sum_{p} X_{c p}$ is the total exports of country $c$ and $1 / \sum_{c} \frac{X_{c p} c}{X_{c}^{0}}$ measures how difficult it is for country $c$ to export product $p$.

We then take this corrected value of total exports (eq. 7) to calculate the second order correction:

$\mathrm{X}_{c}^{2}=\sum_{p} \frac{X_{c p}}{\sum_{c} \frac{X_{c p}}{X_{c}^{1}}}$

where $X_{c}^{2}$ represents the share that a product represents of the average country.

Iterating this to the limit: 
$\mathrm{X}_{c}^{\mathrm{N}}=\sum_{p} \frac{X_{c p}}{\sum_{c} \frac{X_{c p}}{X_{c}^{\mathrm{N}-1}}}$,

and normalizing $X_{c}$ at each iteration step by its geometric mean:

$\mathrm{X}_{c}^{\mathrm{N}}=\frac{X_{c}^{\mathrm{N}}}{\left(\prod_{c^{\prime}} X_{c^{\prime}}\right)^{\frac{1}{[C]}}}$

where $[C]$ is the number of countries in the sample, we estimate the ECI+ as the total exports of a country corrected by how difficult it is to export each product, minus the average share that the country represents in the export of a product (which accounts for the size of a country's export economy):

$E C I_{c}^{+}=\log \left(X_{c}^{\infty}\right)-\log \left(\sum_{p} \frac{X_{c p}}{X_{p}}\right)$.

Placing the spotlight on products instead of countries, PCI+ is defined as the following iterative map:

$\mathrm{X}_{p}^{\mathrm{N}}=\sum_{c} \frac{X_{c p}}{\sum_{p} \frac{X_{c p}}{X_{p}^{\mathrm{N}-1}}}$

with the initial condition $\mathrm{X}_{p}^{0}=\sum_{c} \frac{X_{c p}}{X_{c}^{0}}$ being the average share of product $p$ in country $c$.

Again, normalizing $X_{p}$ at each step by its geometric mean:

$\mathrm{X}_{p}^{\mathrm{N}}=\frac{X_{p}^{\mathrm{N}}}{\left(\prod_{p^{\prime}} X_{p^{\prime}}^{\mathrm{N}}\right)^{\frac{1}{[P]}}}$

where $[P]$ is the number of products in the sample, we define the product complexity index, corrected by how difficult it is to export each product, as

$P C I_{p}^{+}=\log \left(X_{p}\right)-\log \left(X_{p}^{\infty}\right)$

where $X_{p}$ is product $p$ 's total world trade.

To summarize, the ECI+ and the $\mathrm{PCI}+$ denote a measure of the total exports of a country, corrected by how difficult it is to export each product, and a measure of the total trade in a product, corrected by how easy it is to export that product, respectively [8].

Data Availability The data that support the findings of this study are openly available.

Open Access This article is licensed under a Creative Commons Attribution 4.0 International License, which permits use, sharing, adaptation, distribution and reproduction in any medium or format, as long as you give appropriate credit to the original author(s) and the source, provide a link to the Creative Commons licence, and indicate if changes were made. The images or other third party material in this article are included in the article's Creative Commons licence, unless indicated otherwise in a credit line to the material. If material is not included in the article's Creative Commons licence and your intended use is not permitted by statutory regulation or exceeds the permitted use, you will need to obtain permission directly from the copyright holder. To view a copy of this licence, visit http://creativecommons.org/licenses/by/4.0/.

\section{References}

1. Abdon, A., \& Felipe, J. (2011). The product space: What does it say about the opportunities for growth and structural transformation of Sub-Saharan Africa? Levy Economics Institte Working Paper (670).

2. Acaravci, A., \& Ozturk, I. (2010). On the relationship between energy consumption, $\mathrm{CO} 2$ emissions and economic growth in Europe. Energy, 35(12), 5412-5420.

3. Agras, J., \& Chapman, D. (1999). A dynamic approach to the Environmental Kuznets Curve hypothesis. Ecological Economics, 28(2), 267-277.

4. Aiken, L. S., West, S. G., \& Reno, R. R. (1991). Multiple regression: Testing and interpreting interactions. Sage.

5. Akbostanc1, E., Türüt-Aşık, S., \& Tunç, G. İ. (2009). The relationship between income and environment in Turkey: Is there an environmental Kuznets curve? Energy policy, 37(3), 861-867.

6. Al-Mulali, U., \& Ozturk, I. (2015). The effect of energy consumption, urbanization, trade openness, industrial output, and the political stability on the environmental degradation in the MENA (Middle East and North African) region. Energy, 84, 382-389.

7. Albeaik, S., Kaltenberg, M., Alsaleh, M., \& Hidalgo, C. A. (2017a). 729 new measures of economic complexity (Addendum to Improving the Economic Complexity Index). arXiv preprint arXiv: 1708.04107 .

8. Albeaik, S., Kaltenberg, M., Alsaleh, M., \& Hidalgo, C. A. (2017b). Measuring the Knowledge Intensity of Economies with an Improved Measure of Economic Complexity. arXiv preprint arXiv: 1707.05826 .

9. Ang, J. B. (2007). CO2 emissions, energy consumption, and output in France. Energy Policy, 35(10), 4772-4778.

10. Ang, J. B. (2008). Economic development, pollutant emissions and energy consumption in Malaysia. Journal of Policy Modeling, 30(2), 271-278.

11. Antoci, A., Russu, P., Sordi, S., \& Ticci, E. (2014). Industrialization and environmental externalities in a Solow-type model. Journal of Economic Dynamics and Control, 47, 211-224.

12. Antweiler, W., Copeland, B. R., \& Taylor, M. S. (2001). Is free trade good for the environment? American Economic Review, 91(4), 877-908.

13. Asane-Otoo, E. (2015). Carbon footprint and emission determinants in Africa. Energy, 82, 426-435.

14. Balassa, B. (1965). Trade liberalisation and "revealed" comparative advantage. The Manchester School, 33(2), 99-123.

15. Bank, T. W. (2000). World Development Indicators 2000. USA: Oxford University Press.

16. Bimonte, S. (2002). Information access, income distribution, and the Environmental Kuznets Curve. Ecological economics, 41(1), $145-156$.

17. Brooks, N., \& Sethi, R. (1997). The distribution of pollution: community characteristics and exposure to air toxics. Journal of environmental economics and management, 32(2), 233-250.

18. Bustos, S., Gomez, C., Hausmann, R., \& Hidalgo, C. A. (2012). The dynamics of nestedness predicts the evolution of industrial ecosystems. PloS One, 7(11), e49393. 
19. Caldarelli, G., Cristelli, M., Gabrielli, A., Pietronero, L., Scala, A., \& Tacchella, A. (2012). A network analysis of countries' export flows: firm grounds for the building blocks of the economy. PloS One, 7(10), e47278.

20. Can, M., \& Gozgor, G. (2017). The impact of economic complexity on carbon emissions: evidence from France. Environmental Science and Pollution Research, 24(19), 16364-16370.

21. Carpenter, S. R., Caraco, N. F., Correll, D. L., Howarth, R. W., Sharpley, A. N., \& Smith, V. H. (1998). Nonpoint pollution of surface waters with phosphorus and nitrogen. Ecological applications, 8(3), 559-568.

22. Chay, K. Y., \& Greenstone, M. (2005). Does air quality matter? Evidence from the housing market. Journal of political Economy, 113(2), 376-424.

23. Chenery, H. B., \& Taylor, L. (1968). Development patterns: among countries and over time. The Review of Economics and Statistics, 391-416.

24. Cherniwchan, J. (2012). Economic growth, industrialization, and the environment. Resource and Energy Economics, 34(4), 442-467.

25. Chu, L. K. (2020). Economic structure and environmental Kuznets curve hypothesis: new evidence from economic complexity. Applied Economics Letters, 1-5.

26. Clark, C. (1967). The conditions of economic progress. The conditions of economic progress.

27. Cole, M. A. (2007). Corruption, income and the environment: an empirical analysis. Ecological Economics, 62(3-4), 637-647.

28. Cole, M. A., \& Elliott, R. J. (2003). Determining the tradeenvironment composition effect: the role of capital, labor and environmental regulations. Journal of Environmental Economics and Management, 46(3), 363-383.

29. Coondoo, D., \& Dinda, S. (2002). Causality between income and emission: a country group-specific econometric analysis. Ecological Economics, 40(3), 351-367.

30. Cristelli, M., Gabrielli, A., Tacchella, A., Caldarelli, G., \& Pietronero, L. (2013). Measuring the intangibles: A metrics for the economic complexity of countries and products. PloS One, 8(8), e70726.

31. Cristelli, M., Tacchella, A., \& Pietronero, L. (2015). The heterogeneous dynamics of economic complexity. PloS One, 10(2), e0117174.

32. Damania, R., Fredriksson, P. G., \& List, J. A. (2003). Trade liberalization, corruption, and environmental policy formation: theory and evidence. Journal of environmental economics and management, 46(3), 490-512.

33. Dietrich, A. (2012). Does growth cause structural change, or is it the other way around? A dynamic panel data analysis for seven OECD countries. Empirical economics, 43(3), 915-944.

34. Dinda, S. (2004). Environmental Kuznets curve hypothesis: a survey. Ecological economics, 49(4), 431-455.

35. Dinda, S., \& Coondoo, D. (2006). Income and emission: a panel data-based cointegration analysis. Ecological Economics, 57(2), 167-181.

36. Doğan, B., Saboori, B., \& Can, M. (2019). Does economic complexity matter for environmental degradation? An empirical analysis for different stages of development. Environmental Science and Pollution Research, 26(31), 31900-31912.

37. Dominici, F., Greenstone, M., \& Sunstein, C. R. (2014). Particulate matter matters. Science, 344(6181), 257-259.

38. Elgin, C., \& Oztunali, O. (2012). Shadow economies around the world: model based estimates. Bogazici University Department of Economics Working Papers 5(2012), 1-48.

39. EPI. (2014). Environmental Performance Index: Full report and Analysis. New Haven-Palisades: CELP.

40. European Commission (1999). The EU's Eco-Industry's Export Potential. Final report to DGXI of the European Commission .
41. European Environment Agency (2015). Air quality in Europe-2015 report. Tech. Rep. 5. http://www.actu-environnement. com/media/pdf/news-25756-rapport-air-aee.pdf.

42. Farhani, S., Mrizak, S., Chaibi, A., \& Rault, C. (2014). The environmental Kuznets curve and sustainability: A panel data analysis. Energy Policy, 71, 189-198.

43. Feenstra, R. C., Lipsey, R. E., Deng, H., Ma, A. C., \& Mo, H. (2005). World trade flows: 1962-2000. National Bureau of Economic Research: Tech. rep.

44. Felipe, J. (2012). Inclusive Growth, Full Employment, and Structural Change: Implications and Policies for Developing Asia. Anthem Press.

45. FOEN (2011). Environmental Impacts of Swiss Consumption and Production. Tech. rep.

46. Fourastié, J. (1963). Le grand espoir du XXe siècle. Revue Française de Sociologie, 4(2), 224.

47. Frankel, J. A., \& Rose, A. K. (2005). Is trade good or bad for the environment? Sorting out the causality. Review of economics and statistics, 87(1), 85-91.

48. Gala, P., Rocha, I., \& Magacho, G. (2018). The structuralist revenge: economic complexity as an important dimension to evaluate growth and development. Brazilian Journal of Political Economy, 38(2), 219-236.

49. Galeotti, M., Lanza, A., \& Pauli, F. (2006). Reassessing the environmental Kuznets curve for $\mathrm{CO} 2$ emissions: A robustness exercise. Ecological economics, 57(1), 152-163.

50. Galeotti, M., Manera, M., \& Lanza, A. (2009). On the robustness of robustness checks of the environmental Kuznets curve hypothesis. Environmental and Resource Economics, 42(4), 551.

51. Goel, R. K., Herrala, R., \& Mazhar, U. (2013). Institutional quality and environmental pollution: MENA countries versus the rest of the world. Economic Systems, 37(4), 508-521.

52. Gramkow, C., \& Anger-Kraavi, A. (2018). Could fiscal policies induce green innovation in developing countries? The case of Brazilian manufacturing sectors. Climate Policy, 18(2), 246-257.

53. Grossman, G. M., \& Krueger, A. B. (1995). Economic growth and the environment. The quarterly journal of economics, 110(2), 353-377.

54. Hafner, O. (1998). The role of corruption in the misappropriation of tropical forest resources and in tropical forest destruction. Transparency International Working Paper.

55. Halicioglu, F. (2009). An econometric study of CO2 emissions, energy consumption, income and foreign trade in Turkey. Energy Policy, 37(3), 1156-1164.

56. Hall, R. E., \& Jones, C. I. (1999). Why do some countries produce so much more output per worker than others? The quarterly journal of economics, 114(1), 83-116.

57. Hamilton, C., \& Turton, H. (2002). Determinants of emissions growth in OECD countries. Energy Policy, 30(1), 63-71.

58. Hartmann, D., Guevara, M. R., Jara-Figueroa, C., Aristarán, M., \& Hidalgo, C. A. (2017). Linking Economic Complexity, Institutions, and Income Inequality. World Development, 93, 75-93.

59. Hausmann, R., \& Hidalgo, C. A. (2011). The network structure of economic output. Journal of Economic Growth, 16(4), 309-342.

60. Hausmann, R., Hidalgo, C. A., Bustos, S., Coscia, M., Simoes, A., \& Yildirim, M. A. (2014). The atlas of economic complexity: Mapping paths to prosperity. Mit Press.

61. Hausmann, R., Hwang, J., \& Rodrik, D. (2007). What you export matters. Journal of economic growth, 12(1), 1-25.

62. Hidalgo, C. (2015). Why information grows: The evolution of order, from atoms to economies. Basic Books.

63. Hidalgo, C. A., \& Hausmann, R. (2009). The building blocks of economic complexity. proceedings of the national academy of sciences, 106(26), 10570-10575. 
64. Hidalgo, C. A., Klinger, B., Barabási, A.-L., \& Hausmann, R. (2007). The product space conditions the development of nations. Science, 317(5837), 482-487.

65. Hilty, L. M., Arnfalk, P., Erdmann, L., Goodman, J., Lehmann, M., \& Wäger, P. A. (2006). The relevance of information and communication technologies for environmental sustainability-a prospective simulation study. Environmental Modelling \& Software, 21(11), 1618-1629.

66. Holdren, J. P. (1991). Population and the energy problem. Рориlation and environment, 12(3), 231-255.

67. Holtz-Eakin, D., \& Selden, T. M. (1995). Stoking the fires? CO2 emissions and economic growth. Journal of public economics, 57(1), 85-101.

68. Hossain, M. S. (2011). Panel estimation for $\mathrm{CO} 2$ emissions, energy consumption, economic growth, trade openness and urbanization of newly industrialized countries. Energy Policy, 39(11), 6991-6999.

69. Hsu, A., \& Zomer, A. (2014). Environmental performance index (pp. 1-5). Wiley StatsRef: Statistics Reference Online.

70. International Trade Centre. (2001). The Environmental Services Business: Big and Growing. International Trade Forum, 2, 6-9.

71. Jalil, A., \& Mahmud, S. F. (2009). Environment Kuznets curve for $\mathrm{CO} 2$ emissions: A cointegration analysis for China. Energy policy, 37(12), 5167-5172.

72. Jayanthakumaran, K., Verma, R., \& Liu, Y. (2012). CO2 emissions, energy consumption, trade and income: a comparative analysis of China and India. Energy Policy, 42, 450-460.

73. Jorgenson, A. K., \& Clark, B. (2010). Assessing the temporal stability of the population/environment relationship in comparative perspective: a cross-national panel study of carbon dioxide emissions, 1960-2005. Population and Environment, 32(1), 27-41.

74. Kaldor, N. (1967). Strategic factors in economic development. New York State School of Industrial and Labor Relations: Cornell University.

75. Kampa, M., \& Castanas, E. (2008). Human health effects of air pollution. Environmental pollution, 151(2), 362-367.

76. Kasman, A., \& Duman, Y. S. (2015). CO2 emissions, economic growth, energy consumption, trade and urbanization in new EU member and candidate countries: a panel data analysis. Economic Modelling, 44, 97-103.

77. Kaufmann, D., Kraay, A., \& Zoido-Lobaton, P. (1999). Governance Matters. World Bank Policy Research Department. Tech. rep., Working Paper.

78. Kaufmann, R. K., Davidsdottir, B., Garnham, S., \& Pauly, P. (1998). The determinants of atmospheric SO2 concentrations: reconsidering the environmental Kuznets curve. Ecological economics, 25(2), 209-220.

79. Kennett, M., \& Steenblik, R. (2005). Environmental goods and services: A synthesis of country studies, vol. 3. OECD Publishing.

80. Kuznets, S., \& Murphy, J. T. (1966). Modern economic growth: Rate, structure, and spread, vol. 2. Yale University Press New Haven.

81. Lall, S. (1992). Technological capabilities and industrialization. World development, 20(2), 165-186.

82. Lapatinas, A., Litina, A., \& Sartzetakis, E. S. (2018). Environmental projects in the presence of corruption. International Tax and Public Finance, 1-42.

83. Lee, C. C., \& Lee, J. D. (2009). Income and CO2 emissions: evidence from panel unit root and cointegration tests. Energy policy, 37(2), 413-423.

84. Lewis, W. A. (2013). Theory of economic growth, vol. 7. Routledge.

85. Li, H., Mu, H., Zhang, M., \& Gui, S. (2012). Analysis of regional difference on impact factors of China's energy-Related $\mathrm{CO} 2$ emissions. Energy, 39(1), 319-326.
86. Li, K., \& Lin, B. (2015). Impacts of urbanization and industrialization on energy consumption/CO2 emissions: does the level of development matter? Renewable and Sustainable Energy Reviews, 52, 1107-1122.

87. Liddle, B. (2004). Demographic dynamics and per capita environmental impact: Using panel regressions and household decompositions to examine population and transport. Population and Environment, 26(1), 23-39.

88. Liddle, B., \& Lung, S. (2010). Age-structure, urbanization, and climate change in developed countries: revisiting STIRPAT for disaggregated population and consumption-related environmental impacts. Population and Environment, 31(5), 317-343.

89. Lin, C. Y. C., \& Liscow, Z. D. (2012). Endogeneity in the environmental Kuznets curve: An instrumental variables approach. American Journal of Agricultural Economics, 95(2), 268-274.

90. Lin, S., Zhao, D., \& Marinova, D. (2009). Analysis of the environmental impact of China based on STIRPAT model. Environmental Impact Assessment Review, 29(6), 341-347.

91. Lippe, M. (1999). Corruption and environment at the local level. Transparency International Working Paper. Retrieved March 31, 2014.

92. Lisciandra, M., \& Migliardo, C. (2017). An Empirical Study of the Impact of Corruption on Environmental Performance: Evidence from Panel Data. Environmental and Resource Economics, 68(2), 297-318.

93. Lopez, R., \& Mitra, S. (2000). Corruption, pollution, and the Kuznets environment curve. Journal of Environmental Economics and Management, 40(2), 137-150.

94. Madlener, R., \& Sunak, Y. (2011). Impacts of urbanization on urban structures and energy demand: What can we learn for urban energy planning and urbanization management? Sustainable Cities and Society, 1(1), 45-53.

95. Marsiglio, S., Ansuategi, A., \& Gallastegui, M. C. (2016). The environmental Kuznets curve and the structural change hypothesis. Environmental and resource economics, 63(2), 265-288.

96. Martínez-Zarzoso, I., Bengochea-Morancho, A., \& MoralesLage, R. (2007). The impact of population on CO 2 emissions: evidence from European countries. Environmental and Resource Economics, 38(4), 497-512.

97. Martínez-Zarzoso, I., \& Maruotti, A. (2011). The impact of urbanization on $\mathrm{CO} 2$ emissions: evidence from developing countries. Ecological Economics, 70(7), 1344-1353.

98. Mauro, P. (1995). Corruption and growth. The quarterly journal of economics, 110(3), 681-712.

99. Mealy, P., \& Teytelboym, A. (2020). Economic complexity and the green economy. Research Policy, 103948.

100. Neagu, O. (2019). The Link between Economic Complexity and Carbon Emissions in the European Union Countries: A Model Based on the Environmental Kuznets Curve (EKC) Approach. Sustainability, 11(17), 4753.

101. Neagu, O., \& Teodoru, M. C. (2019). The relationship between economic complexity, energy consumption structure and greenhouse gas emission: Heterogeneous panel evidence from the EU countries. Sustainability, 11(2), 497.

102. Nejat, P., Jomehzadeh, F., Taheri, M. M., Gohari, M., \& Majid, M. Z. A. (2015). A global review of energy consumption, CO2 emissions and policy in the residential sector (with an overview of the top ten $\mathrm{CO} 2$ emitting countries). Renewable and sustainable energy reviews, 43, 843-862.

103. OECD. (2016). The Economic Consequences of Outdoor Air Pollution. Tech. rep.

104. Ollo-López, A., \& Aramendía-Muneta, M. E. (2012). ICT impact on competitiveness, innovation and environment. Telematics and Informatics, 29(2), 204-210. 
105. Ozcan, B. (2013). The nexus between carbon emissions, energy consumption and economic growth in Middle East countries: a panel data analysis. Energy Policy, 62, 1138-1147.

106. Panayotou, T. (2016). Economic growth and the environment. The environment in anthropology, 140-148.

107. Pellegrini, L., \& Gerlagh, R. (2006). Corruption, democracy, and environmental policy: an empirical contribution to the debate. The Journal of Environment \& Development, 15(3), 332-354.

108. Ranis, G., \& Fei, J. C. (1961). A theory of economic development. The american economic review, 533-565.

109. Raudenbush, S. W., \& Bryk, A. S. (2002). Hierarchical linear models: Applications and data analysis methods, vol. 1. Sage.

110. Rodrik, D. (2006). What's so special about China's exports? China \& World Economy, 14(5), 1-19.

111. Romm, J. (2002). The internet and the new energy economy. Resources, conservation and recycling, 36(3), 197-210.

112. Samet, J. M., Dominici, F., Curriero, F. C., Coursac, I., \& Zeger, S. L. (2000). Fine particulate air pollution and mortality in 20 US cities, 1987-1994. New England journal of medicine, 343(24), 1742-1749.

113. Sari, R., \& Soytas, U. (2009). Are global warming and economic growth compatible? Evidence from five OPEC countries? Applied Energy, 86(10), 1887-1893.

114. Savci, S. (2012). An agricultural pollutant: chemical fertilizer. International Journal of Environmental Science and Development, 3(1), 73.

115. Saviotti, P. P., \& Frenken, K. (2008). Export variety and the economic performance of countries. Journal of Evolutionary Economics, 18(2), 201-218.

116. Shafiei, S., \& Salim, R. A. (2014). Non-renewable and renewable energy consumption and $\mathrm{CO} 2$ emissions in OECD countries: A comparative analysis. Energy Policy, 66, 547-556.

117. Shafik, N. (1994). Economic development and environmental quality: An econometric analysis. Oxford economic papers, 757-773.

118. Sharma, S. S. (2011). Determinants of carbon dioxide emissions: empirical evidence from 69 countries. Applied Energy, 88(1), 376-382.

119. Sherbinin, A., Carr, D., Cassels, S., \& Jiang, L., (2007). Population and environment. Annual Review of Environment and Resources, 32, 345-373.

120. Sinclair-Desgagné, B. (2008). The environmental goods and services industry. International Review of Environmental and Resource Economics, 2(1), 69-99.

121. Soytas, U., \& Sari, R. (2009). Energy consumption, economic growth, and carbon emissions: challenges faced by an EU candidate member. Ecological economics, 68(6), 1667-1675.

122. Soytas, U., Sari, R., \& Ewing, B. T. (2007). Energy consumption, income, and carbon emissions in the United States. Ecological Economics, 62(3-4), 482-489.

123. Stern, D. I. (2002). Explaining changes in global sulfur emissions: an econometric decomposition approach. Ecological Economics, 42(1-2), 201-220.

124. Stern, D. I. (2004). The rise and fall of the environmental Kuznets curve. World development, 32(8), 1419-1439.

125. Stock, J., \& Yogo, M. (2005). Testing for Weak Instruments in Linear IV Regression, New York: Cambridge University Press. pp. 80-108. URL http://www.economics.harvard.edu/faculty/ stock/files/TestingWeakInstr_Stock\%2BYogo.pdf.

126. Swart, J., \& Brinkmann, L. (2020). Economic complexity and the environment: Evidence from Brazil. In: Universities and Sustainable Communities: Meeting the Goals of the Agenda 2030. Springer, pp. 3-45.
127. Sweet, C. M., \& Maggio, D. S. E. (2015). Do stronger intellectual property rights increase innovation? World Development, 66, 665-677.

128. Tacchella, A., Cristelli, M., Caldarelli, G., Gabrielli, A., \& Pietronero, L. (2012). A new metrics for countries' fitness and products' complexity. Scientific reports, 2, 723.

129. Tacchella, A., Cristelli, M., Caldarelli, G., Gabrielli, A., \& Pietronero, L. (2013). Economic complexity: conceptual grounding of a new metrics for global competitiveness. Journal of Economic Dynamics and Control, 37(8), 1683-1691.

130. Torras, M., \& Boyce, J. K. (1998). Income, inequality, and pollution: a reassessment of the environmental Kuznets curve. Ecological economics, 25(2), 147-160.

131. Tsurumi, T., \& Managi, S. (2010). Decomposition of the environmental Kuznets curve: scale, technique, and composition effects. Environmental Economics and Policy Studies, 11(1-4), 19-36.

132. Wang, C., Chen, J., \& Zou, J. (2005). Decomposition of energyrelated CO2 emission in China: 1957-2000. Energy, 30(1), 73-83.

133. Wang, S., Fang, C., Guan, X., Pang, B., \& Ma, H. (2014). Urbanisation, energy consumption, and carbon dioxide emissions in China: a panel data analysis of China's provinces. Applied Energy, 136, 738-749.

134. Wang, S., Zhou, D., Zhou, P., \& Wang, Q. (2011). CO2 emissions, energy consumption and economic growth in China: A panel data analysis. Energy Policy, 39(9), 4870-4875.

135. Wang, Z., Yang, Z., Zhang, Y., \& Yin, J. (2012). Energy technology patents-CO2 emissions nexus: an empirical analysis from China. Energy Policy, 42, 248-260.

136. Welsch, H. (2004). Corruption, growth, and the environment: a cross-country analysis. Environment and Development Economics, 9(5), 663-693.

137. WHO. (2013). Review of evidence on health aspects of air pollution: REVIHAAP project: final technical report.

138. Xu, B., \& Lin, B. (2015). How industrialization and urbanization process impacts on $\mathrm{CO} 2$ emissions in China: evidence from nonparametric additive regression models. Energy Economics, 48, 188-202.

139. Yilanci, V., \& Pata, U. K. (2020). Investigating the EKC hypothesis for China: the role of economic complexity on ecological footprint. Environmental Science and Pollution Research,. International.

140. York, R., Rosa, E. A., \& Dietz, T. (2003). STIRPAT, IPAT and ImPACT: analytic tools for unpacking the driving forces of environmental impacts. Ecological economics, 46(3), 351-365.

141. Zhang, C., \& Lin, Y. (2012). Panel estimation for urbanization, energy consumption and $\mathrm{CO} 2$ emissions: A regional analysis in China. Energy Policy, 49, 488-498.

142. Zhang, X. P., \& Cheng, X. M. (2009). Energy consumption, carbon emissions, and economic growth in China. Ecological Economics, 68(10), 2706-2712.

143. Zhou, W., Zhu, B., Chen, D., Griffy-Brown, C., Ma, Y., \& Fei, W. (2012). Energy consumption patterns in the process of China's urbanization. Population and Environment, 33(2-3), 202-220.

Publisher's Note Springer Nature remains neutral with regard to jurisdictional claims in published maps and institutional affiliations. 